\title{
Wintertime Easterly and Southeasterly Airflow in the 'Alenuihāhā Channel, Hawaii
}

\author{
David Eugene Hitzl, Yi-Leng Chen, ANd Feng HsiaO \\ Department of Atmospheric Sciences, University of Hawai'i at Mānoa, Honolulu, Hawaii
}

(Manuscript received 21 February 2019, in final form 22 November 2019)

\begin{abstract}
During the wintertime, easterly (E) to southeasterly (SE) flow in the Hawaiian coastal waters is frequent. These wind regimes alter the location and magnitude of channel and tip jet accelerations and the orientation and horizontal extent of the wake zones from east-northeast (ENE) trade wind conditions. The differences are the result of changes in orographic blocking by the Big Island and Maui, with respect to the prevailing wind. During an E wind event, the fastest winds over the 'Alenuihāhā Channel $\left(>9 \mathrm{~m} \mathrm{~s}^{-1}\right)$ occur in the channel exit with sinking of the inversion, which rises again downstream. Although the upstream wind speed is similar to typical summer ENE trade winds $\left(7-8 \mathrm{~m} \mathrm{~s}^{-1}\right)$, the maximum channel wind speed is $3-4 \mathrm{~m} \mathrm{~s}^{-1}$ slower in the exit. The SE flow is characterized by maximum $\left(\sim 6 \mathrm{~m} \mathrm{~s}^{-1}\right)$ northeasterly (NE) channel winds along Maui's south shore and at the channel exit. These winds are the result of orographic blocking on the eastern end of Maui as the northwestern tail of a tip jet off the northeastern coast of the Big Island impinges on Mount Haleakalā. Channel wind speeds are modulated by the speed and direction of this tip jet, which itself varies diurnally and throughout the approach of a midlatitude cold front. Removal of the Big Island shows how the tip jet speed and orientation modulate the pressure gradients and winds in the 'Alenuihāhā Channel. Removal of the Maui County terrain reveals the impact of orographic blocking on the occurrence of channel winds off Maui's south shore.
\end{abstract}

\section{Introduction}

Accelerated winds through coastal mountain gaps are found in many different parts of the world (Overland and Walter 1981; Lackmann and Overland 1989, Mass et al. 1995; Baines 1995) including the Strait of Gibraltar (Dorman et al. 1995; Scorer 1952), Shelikof Strait, Alaska (Lackmann and Overland 1989), and the Gulfs of Tehuantepec and Papagayo (Steenburgh et al. 1998; Schultz et al. 1997, 1998). Strong gap winds, occasionally in excess of $45 \mathrm{~m} \mathrm{~s}^{-1}$, are often preceded by moderate upstream flow and a capping inversion (Reed 1931; Scorer 1952).

For gap flows, the balance of forces in the along-gap direction is an approximate balance between the inertia term and pressure gradient term (Overland and Walter 1981). These flows are typically the strongest in the gap exit. Along-gap pressure gradients are often the result of orographically induced pressure perturbations, with higher pressure on the upwind side of the gap. Some gap flows occur in connection with cold air damming in which a mountain range separates air masses of different

Corresponding author: Yi-Leng Chen, yileng@hawaii.edu properties resulting in large cross-barrier pressure gradients (Sharp and Mass 2004).

Gaberšek and Durran (2004) simulated the airflow over an isolated flattop ridge cut by a straight narrow gap. This experiment showed that the channel flow response is dependent on the normalized mountain height $\left(z=N h_{0} / U\right)$, where $N$ is the Brunt-Väisälä frequency, $h_{0}$ the mountain height, and $U$ the cross-ridge horizontal wind speed. For the linear regime $(z \ll 1)$, there was no enhancement to the gap flow. For the mountain wave regime $(z=\sim 1.5)$, net downward mass flux was important, with strong winds near the gap exit. For the upstream-blocking regime $(z \sim 5)$, lateral convergence generated the strongest winds near the entrance of the gap.

The Island of Hawaii (i.e., Big Island) has a diameter of $\sim 140 \mathrm{~km}$ and is comprised of two large mountains with peaks exceeding $4100 \mathrm{~m}$. Mount Haleakalā on Maui is approximately $3000 \mathrm{~m}$ in height (Fig. 1a). A significant portion of these islands extends above the typical height of the trade wind inversion (TWI) $(\sim 1.9 \mathrm{~km})$ (Winning et al.2017), which serves as a lid, deflecting the low-level incoming airflow around the terrain (Leopold 1949). Summer east-northeast (ENE) trade wind flow may be 

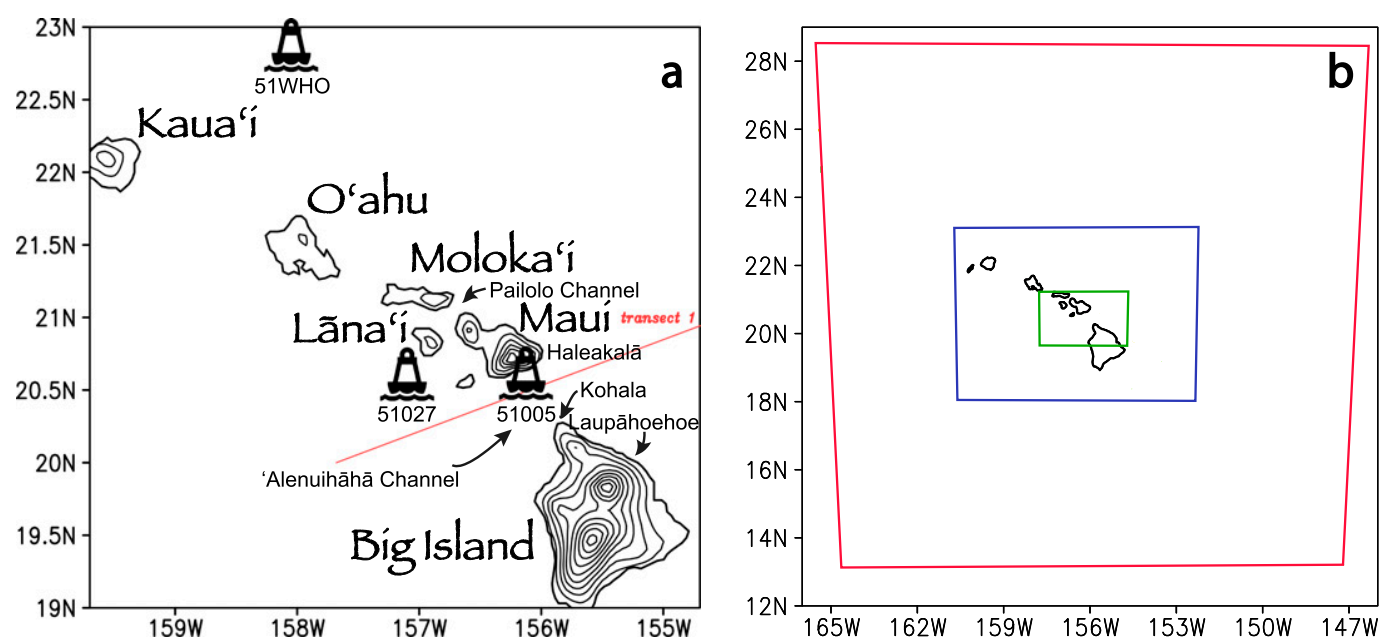

FIG. 1. (a) Locations of buoys 51WHO, 51005, and 51027. Model terrain from the high-resolution nested 2-km model domain with 400-m contour intervals. (b) The three nested domains [18 (red), 6 (blue), and $2 \mathrm{~km}$ (green)] used in the WRF-ARW Model in this study.

described as a combination of an upstream blocking regime and mountain wave regime $(z \sim 1.5)$ with upstream flow deceleration and flow splitting on the windward sides of Maui and the Big Island and strong winds around the tips (tip jets) (Patzert 1969; Smolarkiewicz et al. 1988; Smith 1989; Smolarkiewicz and Rotunno 1989; Schär and Smith 1993; Yang et al. 2005; Carlis et al. 2010). Furthermore, airflow over land and coastal waters is modulated by the diurnal heating cycle (Chen and Nash 1994; Zhang et al. 2005a; Frye and Chen 2001; Esteban and Chen 2008) and affected by diabatic heating associated with orographic clouds and precipitation (Chen and Feng 2001; Nguyen et al. 2010).

The 'Alenuihāhā Channel, which lies between Haleakalā and the Kohala Mountains, has a width of $\sim 50 \mathrm{~km}$ [half a Rossby radius of deformation $\left(L_{R}=N h_{0} / f\right) \sim 10^{2} \mathrm{~km}$, where the Brunt-Väisälä frequency $N \sim 0.6 \times 10^{-2} \mathrm{~s}^{-1}$ and $h_{0}=1.6 \mathrm{~km}$ at approximately $20.4^{\circ} \mathrm{N}$; Overland 1984]. Accelerated winds, a sinking inversion, and a weak hydraulic jump have been observed and simulated in the exit region of this channel under moderate to strong summer ENE trade wind conditions (Smith and Grubišić 1993; Hitzl et al. 2014) and during a wintertime high wind event (Zhang et al. 2005b).

Hitzl et al. (2014) showed that under summer ENE trade winds, 'Alenuihāhā Channel airflow acceleration is driven by orographically induced pressure gradients and net downward mass flux transport by mountain waves above the leeside slopes (Gaberšek and Durran 2004) with strong winds at the gap exit. In addition to orographic blocking, positive pressure perturbations arising from lifting along windward facing slopes and constriction of airflow by the channel itself, the strong along-gap pressure gradient is related to adiabatic warming caused by net downward vertical motions along the ridges bordering the channel below the trade wind inversion. Furthermore, stronger trades $\left(>8 \mathrm{~m} \mathrm{~s}^{-1}\right)$ enhance the sinking of the inversion and likelihood of a hydraulic jump compared to moderate trades $\left(\sim 7 \mathrm{~m} \mathrm{~s}^{-1}\right)$. However, when upstream trade winds were $<7 \mathrm{~m} \mathrm{~s}^{-1}$, a hydraulic jump was unlikely to occur. Diurnal variations in perturbation pressure and airflow descent along the mountains bordering the channel also modulate the along-gap pressure gradients such that channel wind acceleration and the hydraulic jump are greater in the afternoon.

The Hawaiian Islands have two seasons, the cool season (November-April, winter) and the warm season (May-October, summer) with the synoptic airflow primarily determined by the position and strength of the semipermanent North Pacific subtropical high (NPSH). The warm season has a very high frequency of NE trade wind days, with a maximum occurrence in August (>93\%) (Schroeder 1993). During the cool season, the NPSH retreats south and east of its summer position leading to a slight seasonality in the direction of the prevailing winds, which become more $\mathrm{E}$ than ENE. Furthermore, the wintertime wind and surface pressure patterns are influenced by the passages of synoptic disturbances (e.g., Kona lows, cold fronts, upper-level disturbances, etc.) (Blumenstock and Price 1967; Worthley 1967) leading to further variability in the surface winds.

Wintertime southeast (SE) airflow under disturbed large-scale conditions has been observed to alter the location of heavy orographically induced rainfall and island-scale airflow (Kodama and Barnes 1997; Zhang 
TABLE 1. Current and historical buoys used in this study.

\begin{tabular}{lllr}
\hline \hline Buoy & Location & Period of operation & Anemometer height $(\mathrm{m})$ \\
\hline 51000 & $23.538^{\circ} \mathrm{N}, 153.808^{\circ} \mathrm{W}$ & 23 Apr 2009-present & 5 \\
51005 & $20.400^{\circ} \mathrm{N}, 156.100^{\circ} \mathrm{W}$ & 9 Dec 1985-16 Jul 1988 & 5 \\
51027 & $20.400^{\circ} \mathrm{N}, 157.100^{\circ} \mathrm{W}$ & 7 Dec 1994-26 Nov 1995 & 5 \\
$51 \mathrm{WHO}$ & $22.667^{\circ} \mathrm{N}, 157.950^{\circ} \mathrm{W}$ & 14 Aug 2004-present & 3.5 \\
\hline
\end{tabular}

et al. 2005a) over the Hawaiian Islands as compared with summer trade wind conditions (Chen and Nash 1994). Prior to the arrival of a wintertime cold front, the surface airflow turns from $\mathrm{E}$ to ESE. However, less is known on how these airflow changes affect hazardous wind accelerations and vertical motions over the coastal waters.

The purpose of the present research is to study the channel winds under the main wintertime flow regimes based on observations and our model simulations. In addition to buoy observations, we incorporate ship observations and balloon soundings from within the channel into our interpretation of an E flow regime. The present study begins with an overview of wintertime synoptic climatology (2000-09) over the Hawaiian coastal waters (section 3) using the National Centers for Environmental Prediction (NCEP) reanalysis data (Kalnay et al. 1996) and model simulations with a 6-km grid covering the entire state of Hawai'i. The wintertime climatology is compared with the summer conditions presented in Hitzl et al. (2014). Hourly wind reports from the National Data Buoy Center (NDBC) buoys 51005 and 51027, and the Woods Hole Oceanographic Institution buoy 51WHO (Fig. 1a and Table 1) are analyzed to construct seasonal wind roses over the open ocean (51WHO) and downstream of the channel (51005 and 51027) for summer (JJA) and winter (DJF) seasons.

An in depth look at a wintertime E flow event when the RV Kilo Moana traversed the 'Alenuihāhā channel on 2 February 2011 is presented in section 4 . The data collected during the cruise includes ship observations and soundings launched within the channel that provide in situ data to verify model results of weather conditions within the channel and the adjacent areas from the Advanced Research version of the Weather Research and Forecasting (WRF) Model (WRF-ARW; Skamarock and Klemp 2008) with a 2-km grid (Hitzl et al. 2014) on 2 February. The simulated airflow-terrain interaction is analyzed for its effects on tip jet accelerations, vertical motions, and temperature changes in and around the channel and compared with summer ENE trade wind conditions. In section 5, the orographic and diurnal effects of the SE flow regime on vertical motions over the 'Alenuihāhā Channel and adjacent ridges are analyzed to determine their contribution to channel pressure gradients and localized airflow through the channel and the surrounding coastal areas. How the variations in the wind direction under the SE flow regime lead to differences in interaction of the flow with the Big Island and Maui and how this influences the airflow through the channel and wake zones are investigated. Finally, in section 6, two model sensitivity tests illustrate the respective impacts of Maui and Big Island blocking on tip jet development, channel acceleration and wake zones during the SE flow regime.

Studying these airflows and their interactions with local terrain is of value to forecasters, interisland shipping, wave and ocean current modeling, marine resources and management, wind energy assessment, tourism, and public health. The National Weather Service (NWS), for instance, is responsible for issuing small craft advisories in coastal regions where winds exceed $12 \mathrm{~m} \mathrm{~s}^{-1}$. The SE flow, in particular, also transports toxic volcanic emissions (vog) from the Kilauea Volcano to the neighboring islands (Tam et al. 2016).

\section{Data sources, analysis method, and model configuration}

\section{a. Data sources and analysis method}

The four times daily National Centers for Environmental Prediction (NCEP) reanalysis data with a $2.5^{\circ} \times 2.5^{\circ}$ grid are used to construct $10-y r$ seasonal winter climatology over Hawaii and the eastern Pacific. Hourly wind reports from the National Data Buoy Center (NDBC) buoys 51005 and 51027, and 51WHO are used to construct seasonal wind roses and histograms for summer (JJA) and winter (DJF). Buoys 51005 and 51027, operating during the periods of 9 December 1985-16 July 1988 and 7 December 1994-26 November 1995 , respectively, are the only buoys with meteorological instruments deployed in the 'Alenuihāhā Channel region. Buoy 51WHO (WHOI Hawaii Ocean Time series Station) (14 August 2004-7 June 2008) is used as an estimation of synoptic wind conditions over the open ocean.

Winds at 51005 and 51027 are measured at $5 \mathrm{~m}$ (buoy $51 \mathrm{WHO}$ at $3.5 \mathrm{~m}$ ) and averaged over an 8 -min period every hour. Buoys $51 \mathrm{WHO}$ and 51027 have a resolution of $0.1 \mathrm{~m} \mathrm{~s}^{-1}$ and $1^{\circ}$ with $\pm 1 \mathrm{~m} \mathrm{~s}^{-1}$ and $\pm 10^{\circ}$ accuracy. Buoy 51005 has a resolution of $10^{\circ}$ and $\pm 1 \mathrm{~m} \mathrm{~s}^{-1}$ accuracy. 
Observed winds were adjusted to a 10-m height using the wind profile power law with an exponent of 0.11 , assuming near-neutral stability over the ocean (Hsu et al. 1994).

Ship-level and radiosonde data from the Kilo Moana research vessel cruise of 1-10 February 2011 [Cruising Hawai' $i$ with Atmospheric and Oceanographic Students (CHAOS)] (Kapustin et al. 2012) are used to study the surface airflow, sea level pressure, and vertical profiles of wind, temperature, humidity, potential temperature, and inversion height through the 'Alenuihāhā Channel and verify model simulations for a prefrontal $\mathrm{E}$ flow regime. Mast-level wind data has a resolution of $0.1^{\circ}$ and $0.1 \mathrm{~m} \mathrm{~s}^{-1}$, with an accuracy of $\pm 3.0^{\circ}$ and $\pm 0.3 \mathrm{~m} \mathrm{~s}^{-1}$, respectively.

Seven radiosondes were launched using the Lockheed Martin (LMG6) upper-air system during the ship's passage through the 'Alenuihāhā Channel. Low-level sounding wind data has a resolution of $1.0^{\circ}$ and $0.1 \mathrm{~m} \mathrm{~s}^{-1}$, with $\pm 10.0^{\circ}$ and $\pm 1.0 \mathrm{~m} \mathrm{~s}^{-1}$ accuracy. Sounding temperature resolution is $0.01^{\circ} \mathrm{C}$, with an accuracy of $\pm 0.15^{\circ} \mathrm{C}$. Pressure resolution is $0.1 \mathrm{hPa}$ with an accuracy of $\pm 0.5 \mathrm{hPa}$. Relative humidity resolution is $1 \%$ with an accuracy of $2 \%$. The trade wind inversion base height is determined from the temperature and dewpoint profiles.

\section{b. Model configuration}

Similar to Hitzl et al. (2014), the WRF-ARW Model, version 3.3.1, with three nested domains $(18,6$, and $2 \mathrm{~km}$ ) is used (Fig. 1b). The high-resolution 2-km model nested in the 6-km domain with a two-way nesting strategy is needed because of the high spatial variations of airflow and local weather due to the presence of steep terrain (Smolarkiewicz et al. 1988), land-sea thermal contrast (Chen and Nash 1994), diabatic heating associated with clouds and precipitation (Chen and Feng 2001; Nguyen et al. 2010), and scarcity of observations. The details of the model configuration are given in Table 2. A statistical verification of 6-km WRF 10-m ocean surface winds was made for summertime ENE trade wind weather using historical buoy data from the Hawaiian coastal waters and by comparing simulated 10-m ocean surface winds with QuikSCAT winds (Stopa et al. 2011, 2013; Hitzl et al. 2014).

All model runs for February 2011 are initialized with the NCEP Final Analysis (FNL) data with a $1^{\circ} \times 1^{\circ}$ grid. The Noah land surface model (LSM) (Chen and Dudhia 2001) is employed using the land use and soil properties compiled by Zhang et al. (2005a). Soil moisture and soil temperature for the LSM are spun up for two months prior to the simulation period (Zhang et al. 2005a; Yang et al. 2005). The 24-h forecasts of the soil moisture and soil temperature of the previous day are used as the initial boundary conditions at the land surface for the following day's simulation.

The model was run for each day of February 2011 for a 36-h period. A total of 10 of these days $(5,6,10,14,15$, 17, 18, 19, 20, and 21 February) were found to be representative of the SE flow (having a wind direction of $95^{\circ}-135^{\circ}$ at $19.75^{\circ} \mathrm{N}, 154.25^{\circ} \mathrm{W}$ ), and were averaged to create a composite for the study of the diurnal cycle. Sensitivity tests in which the terrain of Maui County (Maui, Moloka'i, Lāna'i, and Kaho'olawe) and the Big Island are removed and replaced with an ocean surface were performed using a day within the composite period representative of $\operatorname{ESE}\left(107^{\circ}\right)$ flow to address the impacts of orographic blocking on the airflow within and in the vicinity of the channel. The islands were removed as in Yang and Chen (2008) and Chen et al. (2018). These authors concluded that four hours of spin up time is sufficient to remove transients. All model runs presented here were spun up for $12 \mathrm{~h}$ (i.e., run for $36 \mathrm{~h}$ of which only the last 24 are used to evaluate the diurnal cycle).

\section{Winter airflow climatology}

\section{a. Mean seasonal synoptic flow}

A 10-yr (2000-09) NCEP reanalysis mean of sea level pressure reveals that the subtropical high pressure cell is $\sim 2 \mathrm{hPa}$ weaker with a center $\sim 5^{\circ}$ farther south and $\sim 15^{\circ}$ farther east during the winter (Fig. 2a) than in summer (Fig. 2b). Mean pressure gradients upstream of the Hawaiian Islands are weaker and more zonal in winter than summer. The mean WRF simulated airflow for winter (Fig. 2c) is characterized by upstream $\mathrm{E}$ to $\mathrm{SE}$ winds of $5-6 \mathrm{~m} \mathrm{~s}^{-1}$. Wind acceleration occurs through channels and around the tips of islands, exceeding $8 \mathrm{~m} \mathrm{~s}^{-1}$ in the 'Alenuihāhā Channel. The orographic influence of the Big Island is considerable with the majority of the leeward coastal waters shadowed from the upstream flow and a westerly reversed flow $\left(\sim 1 \mathrm{~m} \mathrm{~s}^{-1}\right)$ off the leeside coast as found by Patzert (1969), Smolarkiewicz and Rotunno (1989), Schär and Smith (1993), Yang et al. (2005), Hitzl et al. (2014), and others, under trade wind conditions.

The mean WRF summer 10-m winds from the 6-km regional domain for 2000-09 (Fig. 2d) are characterized by ENE trades of $6-8 \mathrm{~ms}^{-1}$ upstream of the islands (Fig. 2d). Orographically induced high pressure extends over $100 \mathrm{~km}$ to the east-northeast of the Big Island. Channel winds and tip jets are faster $\left(9-12 \mathrm{~m} \mathrm{~s}^{-1}\right)$ compared to winter $\left(>8 \mathrm{~m} \mathrm{~s}^{-1}\right)$.

\section{b. Historical buoy observations}

The statistics of large-scale surface winds during the winter season at buoy $51 \mathrm{WHO}$ are given in Fig. 3. 








FIG. 2. (a) Mean winter (DJF) sea level pressure (hPa) during 1 Jan-31 Dec 2000-09 from the NCEP reanalysis; (b) as in (a), but for summer (JJA). (c) Mean 10-m winds ( $\mathrm{m} \mathrm{s}^{-1}$ ) from the WRF-ARW 6-km simulation during the winter for the same period; (d) as in (c), but for summer (JJA).

Winds are $\operatorname{ENE}\left(55^{\circ}-100^{\circ}\right) 45 \%$ of the time (Fig. 3a), southeast $\left(100^{\circ}-145^{\circ}\right) 19 \%$ of the time and southsoutheast $\left(145^{\circ}-190^{\circ}\right) 5.6 \%$ of the time. High wind days $\left(>8 \mathrm{~m} \mathrm{~s}^{-1}\right)$ occur frequently during winter, with over $25 \%$ of days in the $8-10 \mathrm{~m} \mathrm{~s}^{-1}$ range, $21 \%$ in the $10-12 \mathrm{~m} \mathrm{~s}^{-1}$ range, and $6.1 \%$ in the $12-18 \mathrm{~m} \mathrm{~s}^{-1}$ range (Fig. 3a).

Although a direct comparison cannot be made due to gaps in the historical record, a comparison of the winter wind statistics at $51 \mathrm{WHO}$ with those at the channel buoys (51005 and 51027) suggests the influence of local terrain on accelerating and bending the airflow through and downstream of the channel (see appendix A for discrepancies in upwind speed and direction between buoy periods). At buoy 51005, the winter resultant vector $\left(60^{\circ}\right)$ was $30^{\circ}$ more northerly than at $51 \mathrm{WHO}$ (Figs. 3a,d) with a greater proportion of winds $>12 \mathrm{~m} \mathrm{~s}^{-1}(8 \%)$. SE winds were rare at 51005 , with $3.2 \%$ of winds from $100^{\circ}$ to $145^{\circ}$ and $1.8 \%$ from $145^{\circ}$ to $190^{\circ}$. The resultant vector at $51027\left(75^{\circ}\right)$ lay between that of 51005 and 51WHO (Fig. 3g) with similarly few occurrences of SE winds. At 1400 HST, 51005 winds were $5^{\circ}$ more northerly and slightly faster $\left(\sim 1 \mathrm{~m} \mathrm{~s}^{-1}\right)$ on average than at 0500 HST (Figs. 3e,f). Conversely, 1400 HST mean winds at 51027 were $21^{\circ}$ more $\mathrm{E}$ and $\sim 2 \mathrm{~m} \mathrm{~s}^{-1}$ faster than at $0500 \mathrm{HST}$ (Figs. 3h,i). In comparison, the 51WHO resultant vector varied by $<1^{\circ}$ and $0.5 \mathrm{~m} \mathrm{~s}^{-1}$ throughout the diurnal cycle (Figs. 3b,c).

The synoptic climatology and historical buoy data demonstrate orographic effects on the airflow in the 'Alenuihāhā Channel during the winter season. The absence of SE flow readings at the channel buoys suggests that the SE flow is either entirely blocked from the channel or undergoes a drastic change in winds. The buoys also suggest that the diurnal heating cycle enhances the acceleration of winds in the channel in the afternoon. In the following sections, wintertime $\mathrm{E}$ and SE wind events are modeled and investigated to determine the effects of each type of 


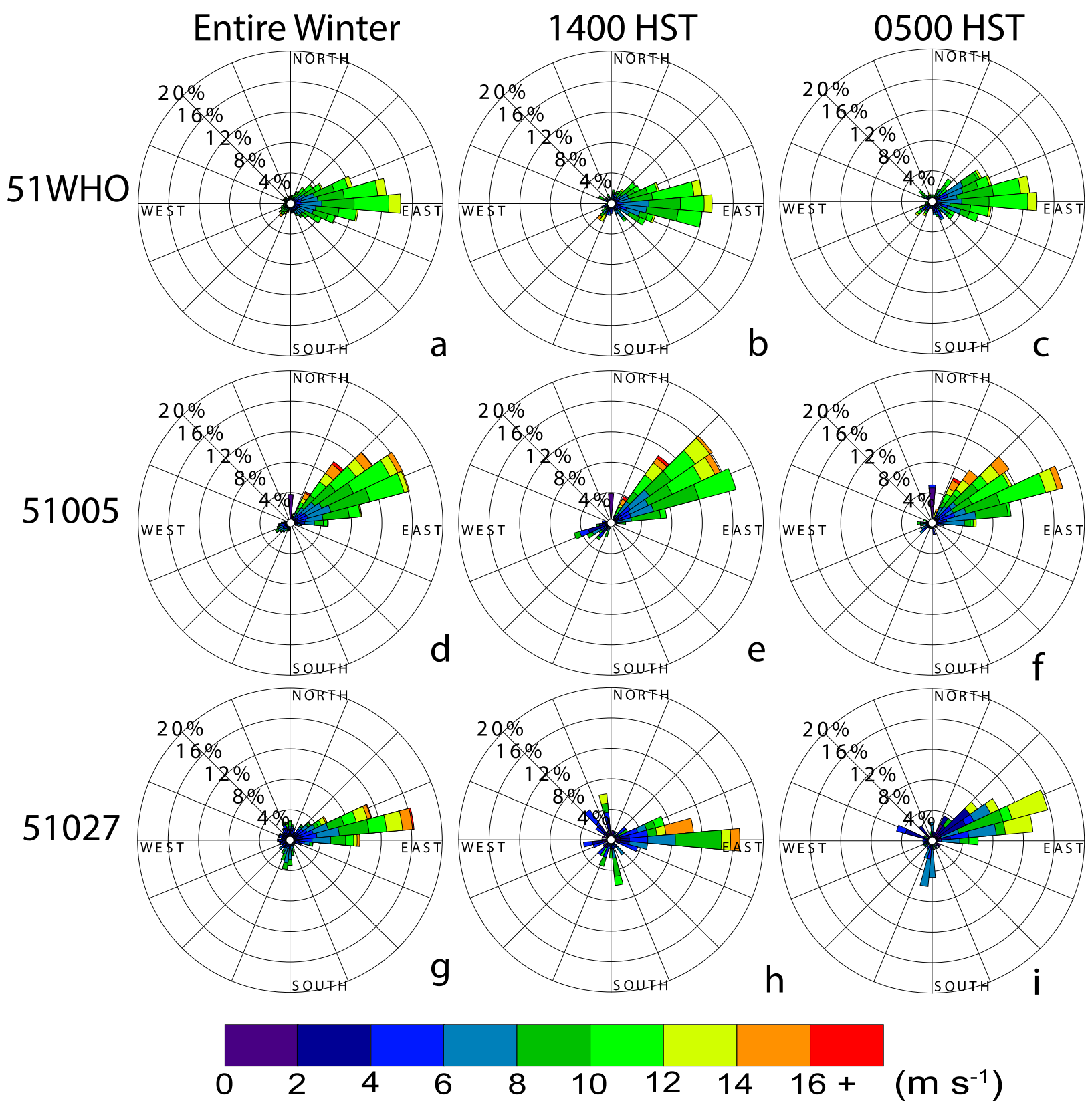

FIG. 3. (a) Winter (DJF) 10-m wind rose at buoy 51WHO during 2004-08. (b),(c) As in (a), but for 1400 and 0500 HST, respectively. (d)-(f) As in (a)-(c), but for buoy 51005 during 1985-88. (g)-(i) As in (a)-(c), but for 51027 during 1994-95.

synoptic event on airflow accelerations near and within the 'Alenuihāhā Channel.

\section{Analysis and modeling of an $E$ flow event in the 'Alenuihāhā Channel}

The mean (0600-1900 HST) simulated 10-m winds and sea level pressure from the 6-km state domain show that $\mathrm{E}$ winds prevailed upstream of the 'Alenuihāhā Channel on 2 February 2011 (Fig. 4a). An elongated
(ENE-WSW) 1030 hPa subtropical high was centered at $37.5^{\circ} \mathrm{N}, 132.5^{\circ} \mathrm{W}$. At this time, a slow, southeastward moving cold front was more than $400 \mathrm{~km}$ northwest of Kauai (not shown), reaching the islands on 6 February. At 1800 UTC 7 February, the shearline associated with the tail end of the front was between Oahu and Maui. Within the next $24 \mathrm{~h}$, the weak front lifted northeastward out of the state of Hawaii as the parent frontal cyclone over the North Pacific advanced NNE (not shown). 



FIG. 4. Mean simulated $10-\mathrm{m}$ winds (shaded, $\mathrm{m} \mathrm{s}^{-1}$ ) and sea level pressure (contours, hPa) from the 6-km state domain. (a) The E flow on 2 Feb 2011 (0600-1900 HST), (b) the 10-day SE composite, (c) the ESE flow of 21 Feb 2011, and (d) the SE true flow of 6 Feb 2011.

Figure 5a shows the mean (0600-1900 HST 2 February 2011) simulated $10-\mathrm{m}$ winds and sea level pressure from the 2-km innermost WRF domain with mast-level $(\sim 10 \mathrm{~m})$ winds from the CHAOS ship track overlaid. The RV Kilo Moana entered the channel exit from the northwest around 0430 HST 2 February, crossed the exit region at 0530 HST, headed ENE toward the Kohala Peninsula around 1130 HST and proceeded NNE across the center of the channel at $\sim 1530$ HST, after which it tracked east. Immediately ahead of the channel entrance, ESE surface winds $\left(100^{\circ}-115^{\circ}\right)$ of $7-8 \mathrm{~m} \mathrm{~s}^{-1}$ were observed (Fig. 5a). At the entrance $\left(\sim 155.75^{\circ} \mathrm{W}\right)$, winds accelerated to $11 \mathrm{~m} \mathrm{~s}^{-1}$, turning counterclockwise to $\mathrm{E}$ $\left(80^{\circ}-90^{\circ}\right)$. Winds peaked at $12 \mathrm{~m} \mathrm{~s}^{-1}$ in the channel exit, having turned $25^{\circ}$ farther counterclockwise, a total turning of $\sim 55^{\circ}$. In the far exit region $\left(\sim 157^{\circ} \mathrm{W}\right)$, winds remained 10 to $11 \mathrm{~m} \mathrm{~s}^{-1}$ with a predominately E direction $\left(\sim 90^{\circ}\right)$.

\section{a. Simulated orographically induced vertical motions, adiabatic temperature adjustments, and airflow}

Around the island chain, simulated wake zones in the 6-km domain undergo a change in their orientation and become broader during prefrontal $\mathrm{E}$ flow with greater impact on neighboring islands (Fig. 4a) as compared to the summer ENE trade wind regime. The wake in the lee of Haleakala is not only broader but also extends westnorthwestward reducing wind speeds over the West Maui Mountains, Molokai, Lānai, and Oahu (Fig. 5a). Winds in the Pailolo Channel, between west Maui and Molokai, are rather weak.

The observed and simulated east-southeasterlies (ESE) approaching the channel on 2 February 2011 are related to orographic blocking by the Big Island as the simulated incoming airflow impinges on the east and southeast facing slopes of the Big Island (Fig. 4a). Orographically induced high pressure occur over the southeastern windward slopes and coastal waters (Fig. 5a) due to adiabatic cooling associated with local rising motion (Fig. 5b). Accelerating SE winds with lower pressure (Fig. 5a) and descending airflow (Fig. 5b) are simulated over the northeast coast of the Big Island downstream of Cape Laupāhoehoe (Fig. 1a), extending northwestward offshore. The strong SE winds $\left(>10 \mathrm{~m} \mathrm{~s}^{-1}\right)$ then impinge on the southeastern end of Haleakalā with splitting airflow on the windward 

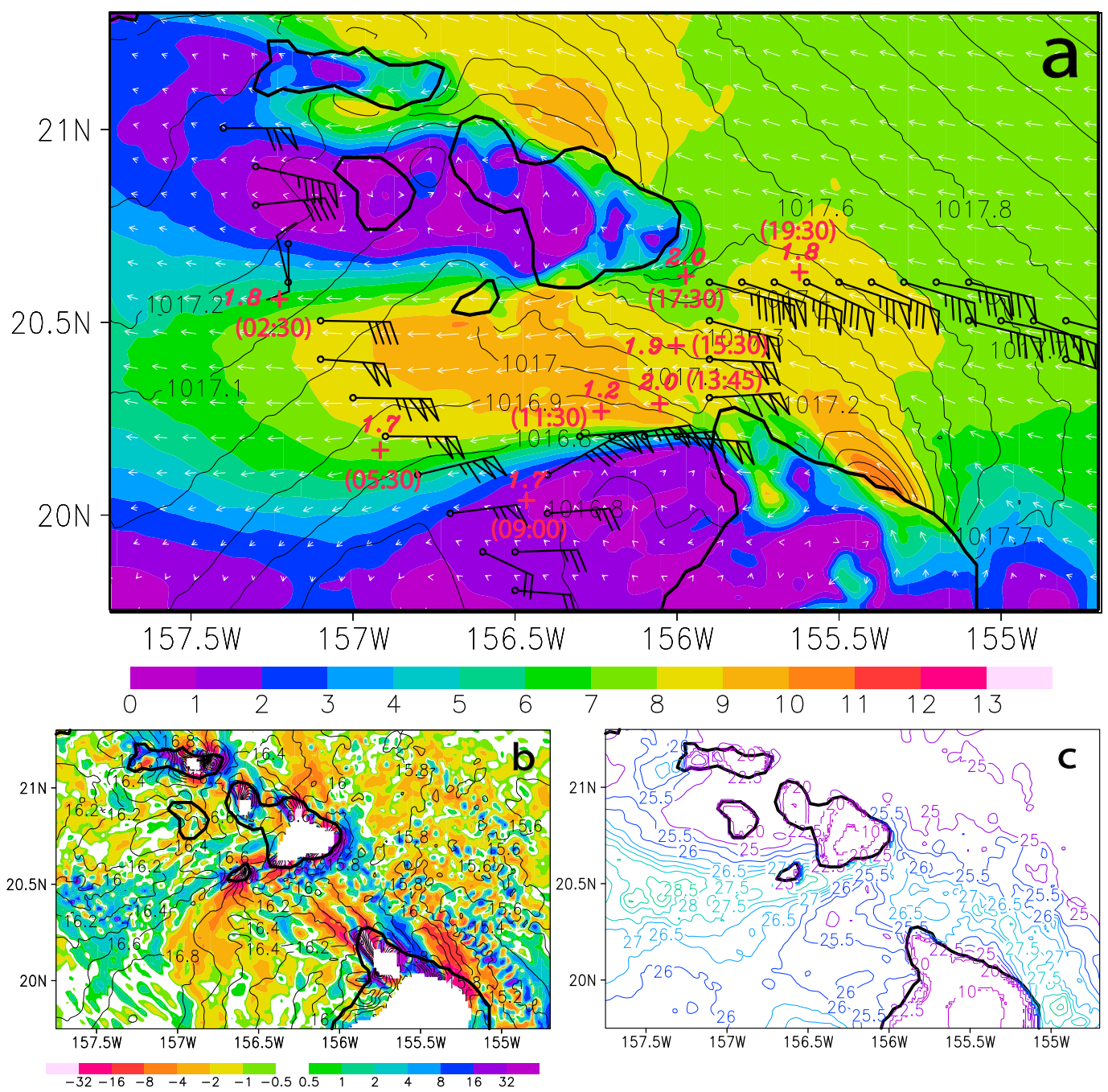

FIG. 5. Mean (0600-1900 HST) simulated meteorological fields from the nested 2-km WRF-ARW domain for the E flow case on 2 Feb 2011. (a) 10-m winds (shaded, $\mathrm{m} \mathrm{s}^{-1}$ ) and sea level pressure (contours, hPa) with mast-level winds ( $\sim 10 \mathrm{~m}$, barbs) from the CHAOS ship track and inversion base heights $(\mathrm{km})$ as determined from sounding data (time $=$ HST) $\left(\right.$ see also Table 3 ) overlaid, (b) air temperature (contours, ${ }^{\circ} \mathrm{C}$ ) and vertical motion at $z=1 \mathrm{~km}$ (shaded, $\mathrm{cm} \mathrm{s}^{-1}$ ), and (c) total precipitable water $(\mathrm{mm})$. Full barb equals $1 \mathrm{~m} \mathrm{~s}^{-1}$, and pennant equals $5 \mathrm{~m} \mathrm{~s}^{-1}$.

side. In the channel entrance, rising motion is present (Fig. 5b) due to convergence of NE winds along the southeastern Maui coast and SE winds off the northeastern Big Island coast (Fig. 5a). Adiabatic warming occurs along the south shore of Maui and throughout the channel exit in association with modest downward vertical motion $\left(1-4 \mathrm{~cm} \mathrm{~s}^{-1}\right)$ but shifts to cooling in the far exit region where upward vertical motion $\left(1-4 \mathrm{~cm} \mathrm{~s}^{-1}\right)$ occurs. Horizontal temperature gradients are largest on the northern side of the channel (Fig. 5b).

Over the subtropics, moisture content in the atmosphere is concentrated in the lower troposphere below the inversion. The simulated TPW is higher off the eastern windward coast of the Big Island due to orographic blocking, and lower downstream of Cape Laupāhoehoe (Fig. 5c) with descending airflow (Fig. 5b). At the entrance of the channel, TPW is higher due to convergence (Fig. 5a) and decreases through the channel with a minimum $(<25 \mathrm{~mm})$ around $20.3^{\circ} \mathrm{N}, 156.3^{\circ} \mathrm{W}$ in the channel exit. The TPW increases farther downstream as the inversion rises. These patterns are confirmed by the inversion heights derived from the soundings taken in the channel (appendix B, Fig. 5a). The variations in TPW are also consistent with the vertical motions.

Model simulations show E mean 10-m winds of $7-8 \mathrm{~m} \mathrm{~s}^{-1}$ upstream of the islands, ESE winds of 8-9 $\mathrm{m} \mathrm{s}^{-1}$ ahead of the channel entrance, and $E$ to ENE winds of $9-10+\mathrm{m} \mathrm{s}^{-1}$ in the channel exit (Fig. 5a). The overall 

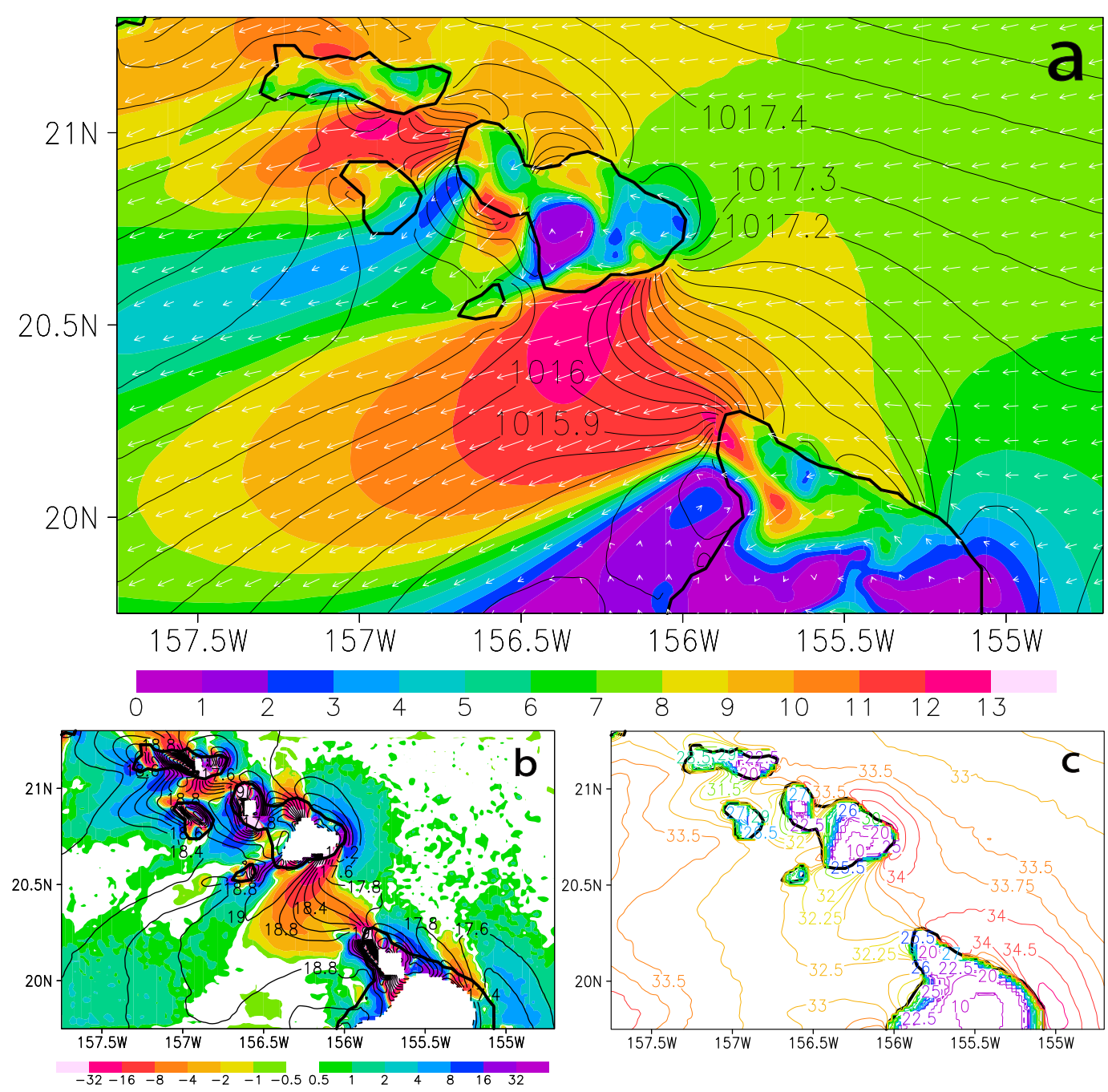

FIG. 6. Mean meteorological fields in the WRF-ARW Model 2-km domain for the ENE trade wind flow of July 2005. (a) 10-m winds (shaded, $\mathrm{m} \mathrm{s}^{-1}$ ) and sea level pressure (contours, hPa), (b) air temperature (contours, ${ }^{\circ} \mathrm{C}$ ) and vertical motion at $z=1 \mathrm{~km}$ (shaded, $\mathrm{cm} \mathrm{s}^{-1}$ ), and (c) total precipitable water (mm) (after Hitzl et al. 2014).

simulated mean airflow resembles ship observations upstream of the channel entrance, but underestimates those in the exit region by $\sim 2 \mathrm{~ms}^{-1}$. This underestimation is reflected in the vertical profiles of model winds which are considerably slower than sounding winds below $950 \mathrm{hPa}$ in the immediate channel exit (appendix C). Some of the discrepancies are attributed to instantaneous measurements by ship observations.

Following a surface streamline, a sea level pressure decrease of $\sim 0.7 \mathrm{hPa}\left(\sim 0.9 \mathrm{~Pa} \mathrm{~km}^{-1}\right)$ was simulated between the channel entrance $\left(\sim 20.7^{\circ} \mathrm{N}, 156^{\circ} \mathrm{W}\right)$ and exit $\left(\sim 20.5^{\circ} \mathrm{N}, 156.6^{\circ} \mathrm{W}\right)$ on the north side of the channel. A pressure decrease of $\sim 0.5 \mathrm{hPa}\left(\sim 0.3 \mathrm{~Pa} \mathrm{~km}^{-1}\right)$ was simulated between the channel entrance $\left(\sim 20.25^{\circ} \mathrm{N}\right.$, $\left.155.2^{\circ} \mathrm{W}\right)$ and exit $\left(\sim 20.4^{\circ} \mathrm{N}, 156.5^{\circ} \mathrm{W}\right)$ on the southern end of the channel. According to the Bernoulli equation
(Overland and Walter 1981; Zhang et al. 2005b; Hitzl et al. 2014), an estimate of the gap exit wind speed, given an initial speed of $5 \mathrm{~m} \mathrm{~s}^{-1}$ and a pressure change of $0.7 \mathrm{hPa}$ is approximately $11.5 \mathrm{~m} \mathrm{~s}^{-1}$. An initial speed of $7 \mathrm{~m} \mathrm{~s}^{-1}$ and a pressure change of $0.5 \mathrm{hPa}$ also yield a final speed of $11.5 \mathrm{~m} \mathrm{~s}^{-1}$. In both examples, the excess $\sim 1.5 \mathrm{~m} \mathrm{~s}^{-1}$ in the Bernoulli calculation over the model wind speed may be ascribed to friction (Mass et al. 1995), however, the time averaging of the model results may also be a factor.

\section{b. E flow and ENE trade wind comparison}

The simulated airflow acceleration in the 'Alenuihāhā Channel is markedly slower in the E flow regime (Fig. 5a) as compared with the summer ENE trade wind simulations (Fig. 6a) despite similar upstream 

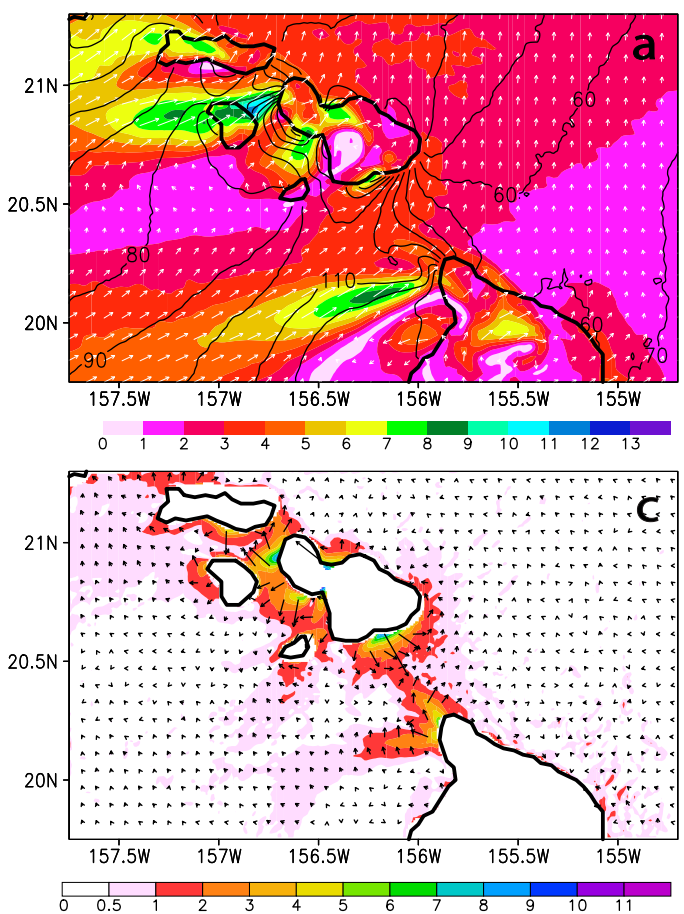

wind speeds. Maximum winds are $3-4 \mathrm{~m} \mathrm{~s}^{-1}$ slower in the channel center and $5-6 \mathrm{~ms} \mathrm{~s}^{-1}$ slower near the southern coast of Haleakalā in response to smaller pressure gradients within the channel.

In both $\mathrm{E}$ and $\mathrm{SE}$ wind regimes, strong southeasterlies exist downstream of Cape Laupāhoehoe (Figs. 5a and $6 a)$. These winds become stronger as the upstream flow turns from ENE to $\mathrm{E}$ and pressure decreases in the lee of the cape (Figs. 5a and 6a). During the $\mathrm{E}$ flow regime, orographic blocking occurs on the eastern side of the Big Island while the northern branch of the splitting airflow moves across the eastern ridgeline of Mauna Kea, descending in the leeside of Cape Laupāhoehoe.

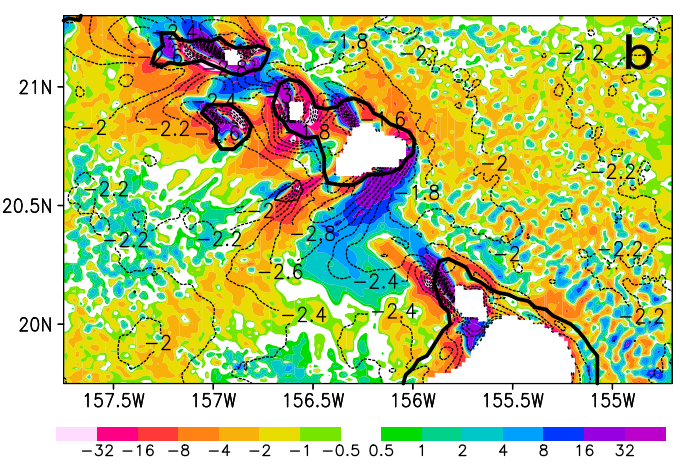

FIG. 7. A subtraction of July 2005 from 2 Feb 2011 (0600-1900 HST) for the (a) mean 10-m winds (shaded, $\mathrm{ms}^{-1}$ ) and sea level pressure (contours, Pa), (b) mean air temperature (contours, ${ }^{\circ} \mathrm{C}$ ) and vertical motion at $z=1 \mathrm{~km}$ (shaded, $\mathrm{cm} \mathrm{s}^{-1}$ ), and (c) mean sea level pressure gradients $\left(\mathrm{Pa} \mathrm{km}^{-1}\right)$.
Descending airflow from the crest of the Kohala Mountains to the southern part of the channel entrance produces lower pressure north of the Kohala Mountains (Fig. 5a). The descending airflow in the lee of Cape Laupāhoehoe and the Kohala Mountains leads to a reduction in the channel pressure gradients, particularly in the southern half, compared to the ENE flow regime.

The orientation of winds within the 'Alenuihāhā Channel and downstream of the channel exit is dependent on the direction of the upstream flow (Figs. 5a and 6a) The ENE flow with significant orographic blocking by both the Kohala Mountains and Haleakalā,

TABLE 3. Estimations of Froude number (Fr) based on the CHAOS cruise soundings of 2 Feb 2011. Mean potential temperature below the inversion, potential temperature difference across the inversion, inversion base height, gravity wave speed, and mean wind speed below the inversion for each sounding are computed and used for the estimation of Fr.

\begin{tabular}{|c|c|c|c|c|c|c|c|}
\hline $\begin{array}{l}\text { Time } \\
\text { (HST) }\end{array}$ & Position & $\begin{array}{l}\text { Mean potential } \\
\text { temperature } \\
\text { below the } \\
\text { inversion } \bar{\theta}(\mathrm{K})\end{array}$ & $\begin{array}{c}\text { Potential } \\
\text { temperature } \\
\text { difference across } \\
\text { the inversion } \\
\Delta \theta(\mathrm{K})\end{array}$ & $\begin{array}{c}\text { Inversion base } \\
\text { height }(H) \\
(\mathrm{m}, \mathrm{hPa})\end{array}$ & $\begin{array}{c}\text { Gravity wave } \\
\text { speed } \\
\text { (c) }\left(\mathrm{m} \mathrm{s}^{-1}\right)\end{array}$ & $\begin{array}{l}\text { Mean wind speed } \\
\text { below the } \\
\text { inversion } \\
\text { base }(U)\left(\mathrm{m} \mathrm{s}^{-1}\right)\end{array}$ & $\begin{array}{c}\text { Froude } \\
\text { number } \\
\text { (Fr) }\end{array}$ \\
\hline 0230 & $20.56^{\circ} \mathrm{N}, 157.23^{\circ} \mathrm{W}$ & 297.9 & 2.6 & 1840,820 & 12.6 & 6.8 & 0.5 \\
\hline 0530 & $20.17^{\circ} \mathrm{N}, 156.92^{\circ} \mathrm{W}$ & 297.6 & 1.3 & 1650,840 & 8.4 & 8.4 & 1.0 \\
\hline 1130 & $20.27^{\circ} \mathrm{N}, 156.24^{\circ} \mathrm{W}$ & 296.6 & 0.8 & 1240,880 & 5.7 & 8.6 & 1.5 \\
\hline 1345 & $20.29^{\circ} \mathrm{N}, 156.06^{\circ} \mathrm{W}$ & 298.4 & 3.3 & 2040,800 & 14.9 & 4.6 & 0.3 \\
\hline 1530 & $20.44^{\circ} \mathrm{N}, 156.01^{\circ} \mathrm{W}$ & 297.8 & 1.9 & 1940,810 & 11.0 & 8.7 & 0.8 \\
\hline 1730 & $20.62^{\circ} \mathrm{N}, 155.98^{\circ} \mathrm{W}$ & 297.5 & 4.8 & 1980,805 & 17.7 & 7.0 & 0.4 \\
\hline 1930 & $20.62^{\circ} \mathrm{N}, 155.63^{\circ} \mathrm{W}$ & 297.0 & 2.6 & 1825,820 & 12.5 & 7.5 & 0.6 \\
\hline
\end{tabular}




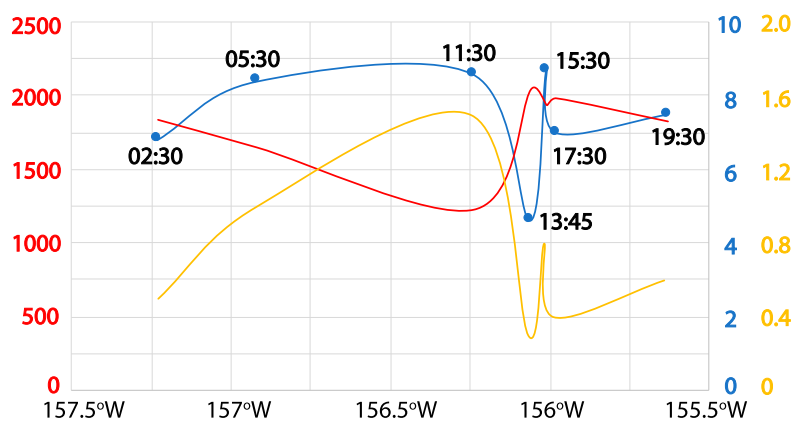

FIG. 8. Mean wind speed below the inversion $\left(\mathrm{m} \mathrm{s}^{-1}\right.$, blue), inversion base height ( $\mathrm{m}$, red), and Froude number (orange) through the 'Alenuihāhā Channel based on sounding data from 2 Feb 2011 with sounding times (HST) overlaid (see also Table 3).

enhances the channel entrance convergence and exit region sinking (Fig. 6b). Pressure gradients on the southern side of the channel are enhanced by the Kohala Mountains during ENE flow with lower pressure in the lee. Wind speeds are $8-9 \mathrm{~m} \mathrm{~s}^{-1}$ greater in the leeward waters of Kohala (Fig. 7a) and $4-5 \mathrm{~m} \mathrm{~s}^{-1}$ faster along the ridges. Over the northern part of the channel exit, downward vertical motion is more significant under ENE flow than E flow (Figs. 5b and $6 \mathrm{~b}$ ) resulting in acceleration along the south shore of Maui (Figs. 5a and 6a). The summer ENE flow also has higher moisture content (TPW) on the windward side of both islands and in the channel entrance, and lower moisture content in the channel exit, consistent with vertical motion patterns (Figs. 6b,c).

Horizontal temperature perturbations are larger in the ENE flow than the $\mathrm{E}$ flow by $\sim 1^{\circ} \mathrm{C}$ on the northern side of the channel, $\sim 0.4^{\circ} \mathrm{C}$ in the center of the channel, and $\sim 0.8^{\circ} \mathrm{C}$ along the northwest tip of Kohala at a height of $1000 \mathrm{~m}$ (Fig. 7b) with larger horizontal pressure gradients (Fig. $7 \mathrm{c}$ ) including $1-2 \mathrm{~Pa} \mathrm{~km}^{-1}$ in the channel center, $3-8 \mathrm{~Pa} \mathrm{~km}^{-1}$ on the northern side of the channel, and up to $5 \mathrm{~Pa} \mathrm{~km}^{-1}$ off the tip of Kohala (Fig. 7c).

In summary, a modest change in upstream wind direction $\left(<40^{\circ}\right)$ significantly alters the location, orientation and intensity of channel wind accelerations and the wake zone. These changes are related to differences in orographic blocking associated with the Big Island and Mount Haleakalā on Maui under E wind conditions. The orientation of upstream winds and the corresponding location and magnitude of vertical motions and temperature adjustments yield weaker
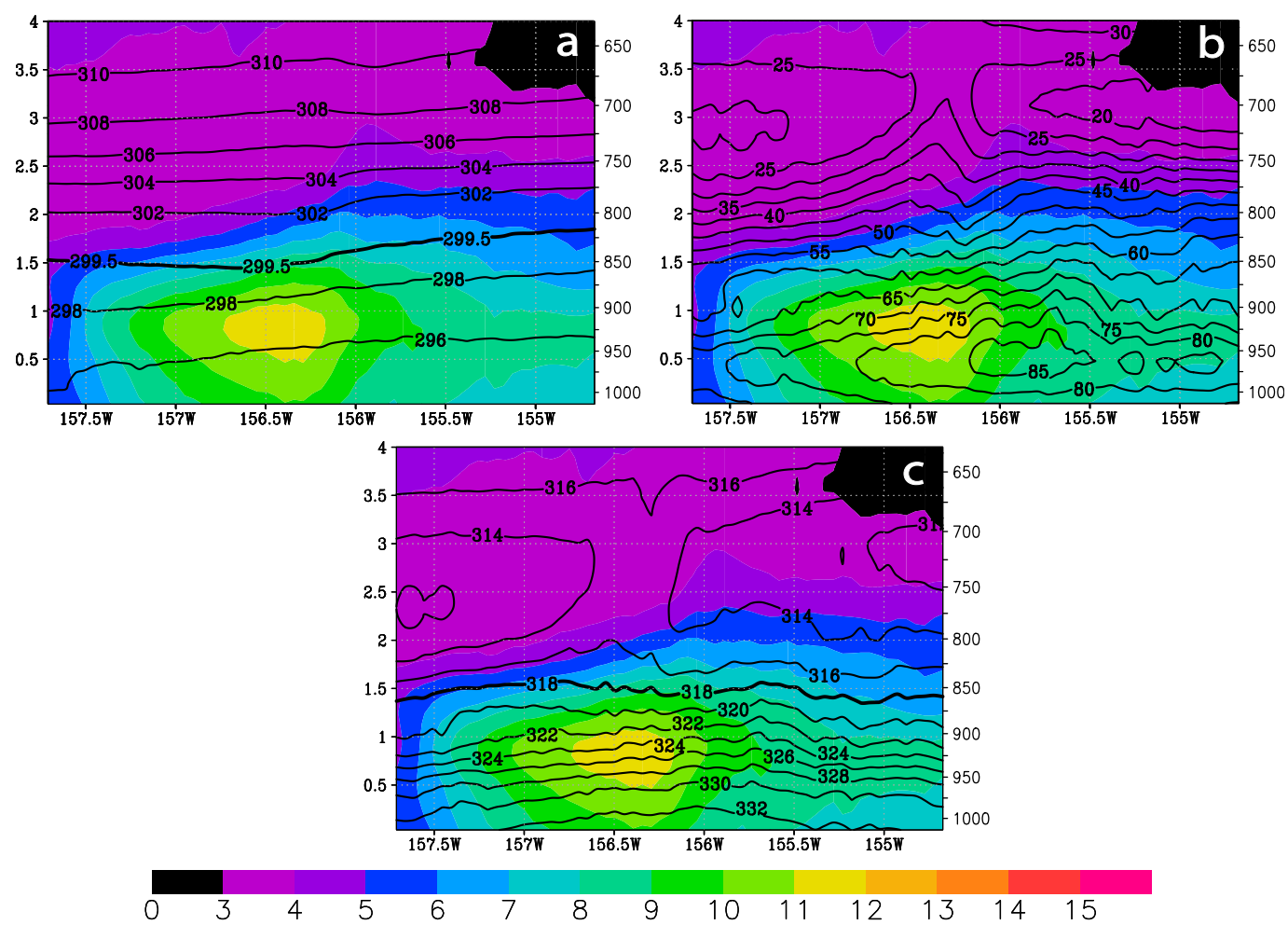

FIG. 9. Mean simulated wind component ( shaded, $\mathrm{m} \mathrm{s}^{-1}$ ) from the 2-km nested domain for the E flow case on 2 Feb 2011 (0000-2300 HST) along transect 1 of Hitzl et al. (2014) (Fig. 1a) and (a) potential temperature (black contours, K), (b) relative humidity (contours, \%), and (c) equivalent potential temperature (contours, K). 


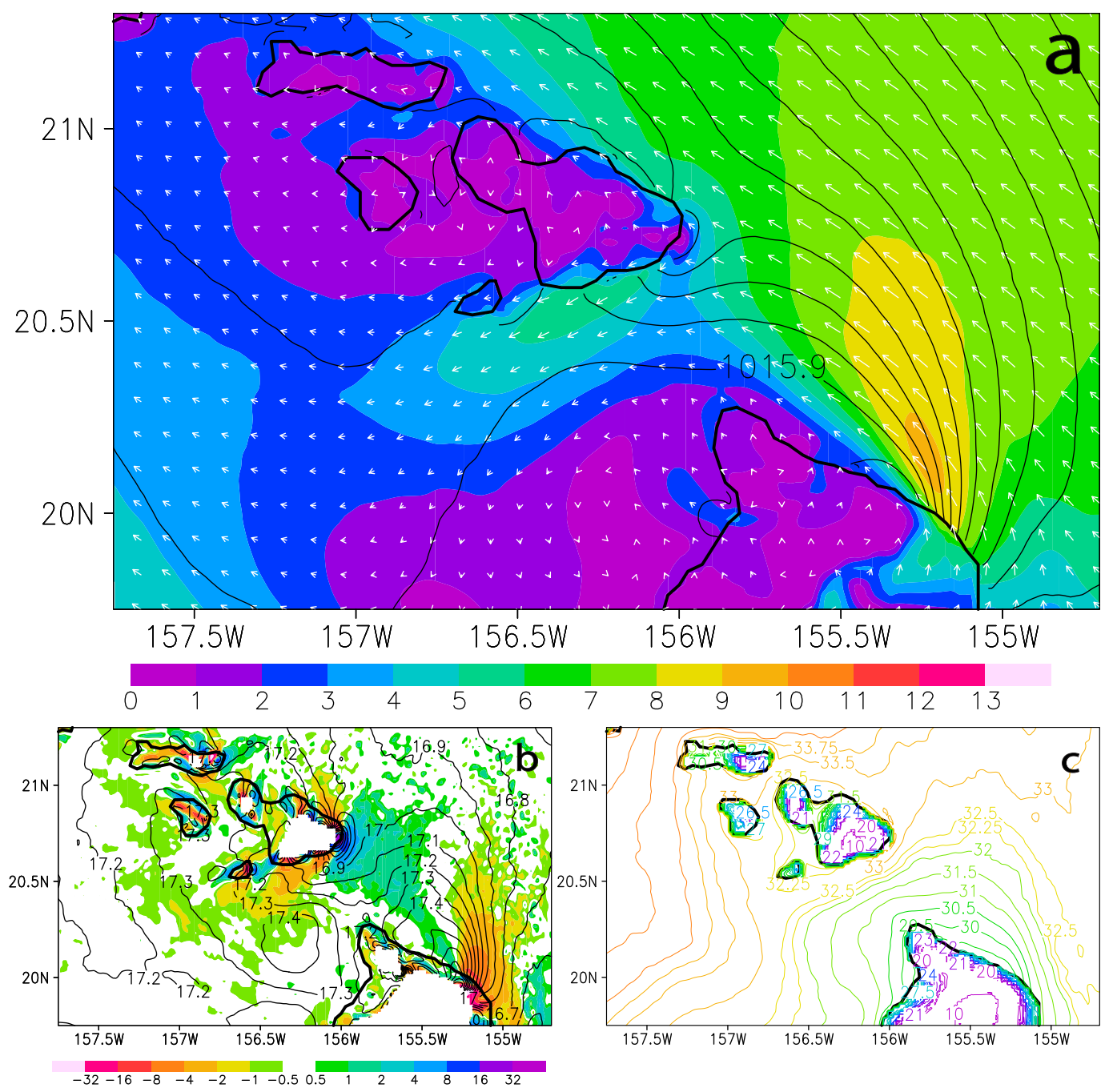

FIG. 10. Mean simulated meteorological fields from the 2-km nested domain for the 10-day SE composite. (a) 10$\mathrm{m}$ winds (shaded, $\mathrm{m} \mathrm{s}^{-1}$ ) and sea level pressure (contours, $\mathrm{hPa}$ ), (b) air temperature (contours, ${ }^{\circ} \mathrm{C}$ ) and vertical motion at $z=1 \mathrm{~km}$ (shaded, $\mathrm{cm} \mathrm{s}^{-1}$ ), and (c) total precipitable water ( $\mathrm{mm}$ ).

channel pressure gradients for E flow than for summer ENE flow.

\section{c. Airflow, vertical thermodynamic profiles, and inversion base height variation through the 'Alenuihāhā Channel}

As mentioned in section 1, a hydraulic jump has been shown to exist in the 'Alenuihāhā Channel during moderate summertime trade wind conditions. In this section we investigate the likelihood of a hydraulic jump occurring during the E flow regime of 2 February 2011.

The existence of a jump may occur if a region of supercritical flow exists along the channel airflow path. Supercritical flow can be identified if the Froude number $(\mathrm{Fr}=U / c)$ is greater than 1 , where $c$ is the gravity wave speed given by $c=\sqrt{\Delta \theta g H / \bar{\theta}}, H$ is the inversion base height, $\Delta \theta$ is the potential temperature difference across the inversion, and $\bar{\theta}$ is the mean potential temperature below the inversion. Table 3 shows the calculation of $\mathrm{Fr}$ based on data from each sounding within the channel (Fig. 5a). The Froude number meets or exceeds unity at two sounding locations in the channel exit indicating the likelihood of a hydraulic jump for this particular case.

Appendix $\mathrm{C}$ shows the wind profiles of the soundings and $2-\mathrm{km}$ model simulations. The fastest winds lie below $925 \mathrm{hPa}$ in the $0530 \mathrm{HST}$ sounding and near the surface at 1130 HST. These winds correspond with the lowest inversion heights among all the soundings (appendix B, Fig. 8), with acceleration near the surface and deceleration aloft. These patterns are in line with the descent of the inversion and subsequent hydraulic jump described by Smith and Grubišić (1993, their Fig. 12) and Hitzl et al. 



(2014). The Fr values exceed unity in the channel exit with $\mathrm{Fr} \sim 1.0$ at $20.17^{\circ} \mathrm{N}, 156.92^{\circ} \mathrm{W}$ and $\mathrm{Fr} \sim 1.5$ at $20.27^{\circ} \mathrm{N}$, $156.24^{\circ} \mathrm{W}$ (Table 3 and Fig. 8). Thus, a hydraulic jump is likely to exist in the channel during this $\mathrm{E}$ flow event. The 1345 HST sounding exhibits acceleration at the surface and deceleration aloft but has a low Fr (0.3) due to the increased height of the inversion related to blocking by the Kohala Peninsula (Figs. 5a-c). Observed spatial variations of inversion height throughout the channel are consistent with simulated variations in TPW (Fig. 5c).

Taking an upstream inversion base height of $\sim 820 \mathrm{hPa}$, based on the 1930 HST sounding $(\sim 1.8 \mathrm{~km})$, and following a simulated mean isentrope from this point along the $\sim 299.5 \mathrm{~K}$ contour in the vertical cross section indicated by transect 1 (Fig. 1a) shows the potential temperature surface descending from the channel center into the exit region $\left(\sim 156.2^{\circ} \mathrm{W}\right)$ to a height of $\sim 1.4 \mathrm{~km}$, or $\sim 860 \mathrm{hPa}$ (Fig. 9a), mirroring the inversion descent in the sounding data. Simulated relative humidity and equivalent potential temperature contours (Figs. 9b,c) also mirror the sinking of the inversion beginning near the channel entrance. An increase in $\mathrm{RH}$ and the equivalent potential temperature above $1.5 \mathrm{~km}$ near $156.4^{\circ} \mathrm{W}$ (Figs. 9b,c) reflects a rebound in the inversion height, indicative of the presence of a hydraulic jump.

\section{Simulations of the SE flow regime}

In this section, the airflow in the 'Alenuihāhā Channel and the diurnal cycle for a 10-day SE flow composite are

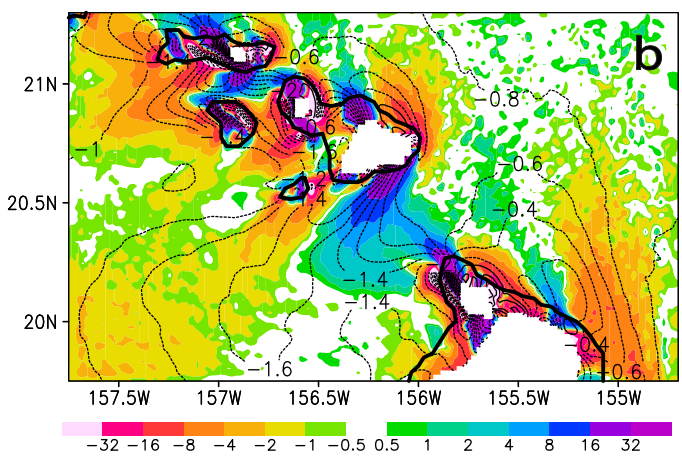

FIG. 11. Subtraction of the mean simulated July 2005 meteorological fields from the SE composite in the nested $2-\mathrm{km}$ domain for the (a) $10-\mathrm{m}$ winds (shaded, $\mathrm{m} \mathrm{s}^{-1}$ ) and sea level pressure (contours, $\mathrm{Pa}$ ), (b) air temperature (contours, ${ }^{\circ} \mathrm{C}$ ) and vertical motion at $z=1 \mathrm{~km}$ (shaded, $\mathrm{cm} \mathrm{s}^{-1}$ ), and (c) sea level pressure gradients $\left(\mathrm{Pa} \mathrm{km}^{-1}\right)$.

analyzed. There are variations in the SE flow. Impacts of variations in the SE flow on airflow through the channel are also investigated. The daily mean simulated flow for the 6-km regional domain is given in appendix D. Effects of orographic blocking by the Big Island and Oahu are investigated by model sensitivity tests.

\section{a. Mean flow, pressure gradients, and vertical motions}

In the regional domain with a 6-km grid, the SE flow is characterized by orographic blocking over the southeastern slopes of the Big Island $\left(\sim 19.5^{\circ} \mathrm{N}\right)$ with orographically induced high pressure there (Fig. 4b). The entire island chain is in the Big Island's wake zone. The southeast flow composite (Fig. 4b) exhibits weak airflow throughout the channel region, particularly in the southern portion, greater tip jet acceleration along Laupāhoehoe, and more profound wake effects downstream of Maui and the Big Island as compared with the ENE flow.

In the high-resolution 2-km nested domain, the Laupāhoehoe tip jet, with a broad region of downward motion in the leeside of the cape (Figs. 10a,b), is more prominent as compared to the ENE trade wind regime. Relatively weak NE channel winds, with a maximum speed $>5 \mathrm{~m} \mathrm{~s}^{-1}$, are simulated off the south shore of Maui (Fig. 10a). The tip jet impinges on the eastern end of Haleakalā with rising motion of $8-16 \mathrm{~cm} \mathrm{~s}^{-1}$ (Fig. 10b) and higher pressure (Fig. 10a). The incoming flow decelerates with splitting airflow off the eastern coast of Maui. Downward motion $\left(1-4 \mathrm{~cm} \mathrm{~s}^{-1}\right)$ with warming 



FIG. 12. Mean simulated 10-m winds (shaded, $\mathrm{m} \mathrm{s}^{-1}$ ) and sea level pressure (contours, hPa) from the 2-km nested domain for the 10-day SE composite at (a) 1400 and (b) 0500 HST. (c),(d) As in (a),(b), but for air temperature (contours, ${ }^{\circ} \mathrm{C}$ ) and vertical motion at $z=1 \mathrm{~km}$ (shaded, $\mathrm{cm} \mathrm{s}^{-1}$ ). (e),(f) As in (a),(b), but for total precipitable water (mm).

and lower pressure are simulated off the northeastern and southern coasts of Maui (Fig. 10b).

Channel airflow is accelerated by pressure gradients off Maui's southern coast. The NE winds $\left(5-6 \mathrm{~m} \mathrm{~s}^{-1}\right)$ are in response to $1-2+\mathrm{Pa} \mathrm{km}^{-1} \mathrm{NE}-\mathrm{SW}$ oriented pressure gradients. The 1000-m horizontal temperature distribution correlates well with vertical motions and local pressure gradients, especially along the SE coast of Maui and at Laupāhoehoe (up to $4 \mathrm{~Pa} \mathrm{~km}^{-1}$ ) (Fig. 10b). The TPW distribution reveals drier air over the coastal waters of the northern Big Island due to descending SE winds (Fig. 10c). The TPW is higher on the eastern windward coast of Maui as a result of lifting of moist air on the windward slopes, which increases the height of the inversion base.
Channel winds are substantially slower in the SE composite as compared to the ENE trade wind regime, particularly in the southern portion of the channel (Figs. 11a,c). The trade wind case has greater adiabatic cooling on the windward sides of Maui and the Big Island $\left(0.5^{\circ}-1^{\circ} \mathrm{C}\right)$ and greater warming in the channel exit $\left(1^{\circ}-1.5^{\circ} \mathrm{C}\right)$ (Fig. 11b). This results in greater channel pressure gradients $\left(2-9 \mathrm{~Pa} \mathrm{~km}^{-1}\right.$ on the northern side of the channel, $1-2 \mathrm{~Pa} \mathrm{~km}^{-1}$ in the channel center, and 2-9 $\mathrm{Pa} \mathrm{km}^{-1}$ off the tip of Kohala) (Fig. 11c).

\section{b. Diurnal variations}

In the SE composite, channel mean winds are $1-3 \mathrm{~m} \mathrm{~s}^{-1}$ faster with more E direction in the afternoon (Fig. 12a) 

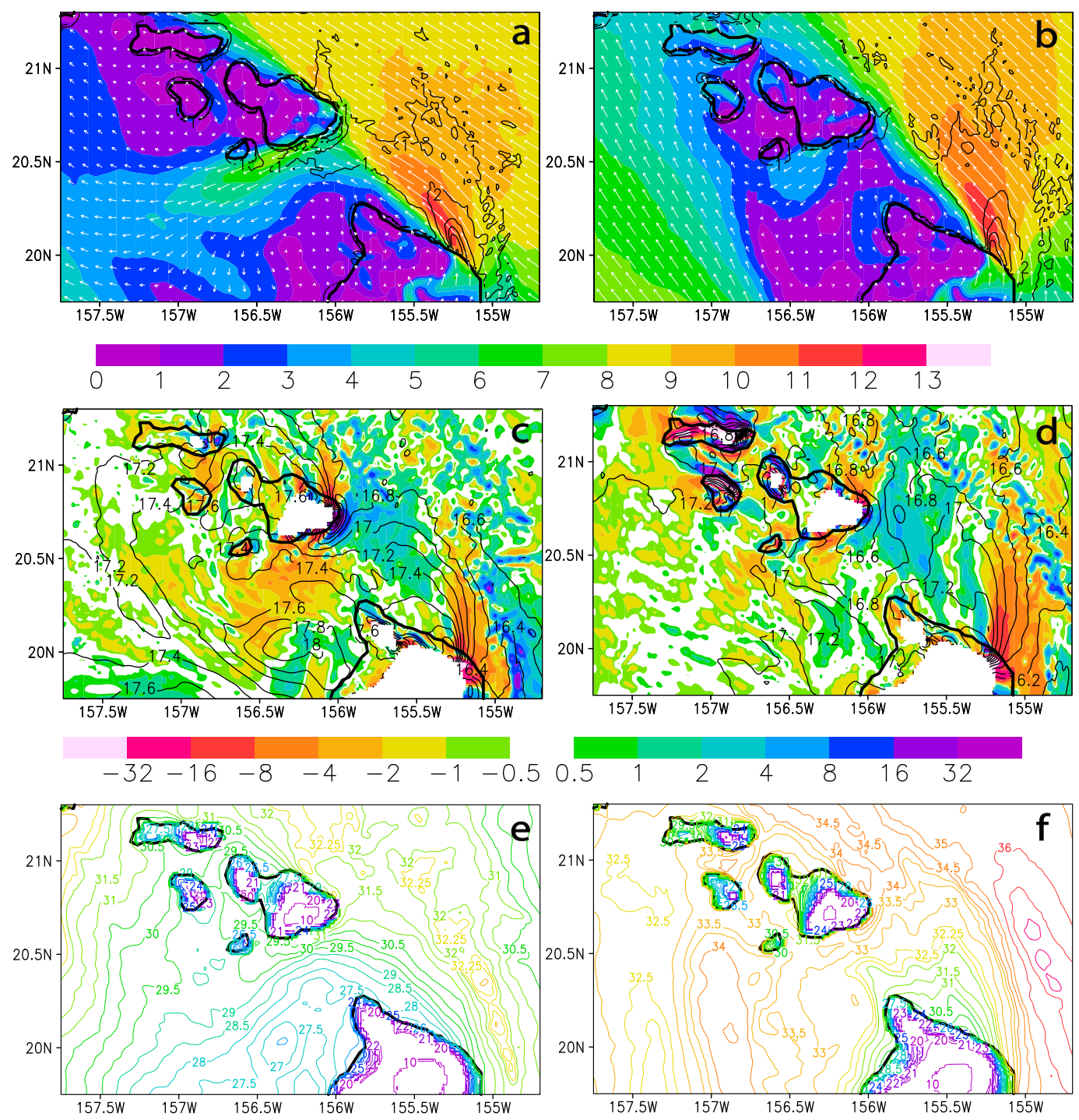

FIG. 13. Mean simulated $10-\mathrm{m}$ winds (shaded, $\mathrm{m} \mathrm{s}^{-1}$ ) and the magnitude of sea level pressure gradients (contours, $\mathrm{Pa} \mathrm{km}^{-1}$ ) for the (a) ESE flow case on $21 \mathrm{Feb}$ and (b) SE true flow case on 6 Feb. (c),(d) Air temperature (contours, ${ }^{\circ} \mathrm{C}$ ) and vertical motion at $z=1 \mathrm{~km}$ (shaded, $\mathrm{cm} \mathrm{s}^{-1}$ ) on $21 \mathrm{Feb}$ and $6 \mathrm{Feb}$, respectively. (e),(f) As in (c),(d), but for total precipitable water $(\mathrm{mm})$.

in agreement with buoy 51027 (Figs. 3h,i). In the early morning, orographic blocking is more significant on the windward side of Maui and the Big Island as evidenced by more significant airflow splitting (Figs. 12a,b). Furthermore, TPW is higher off the windward coast of Maui and over the eastern Big Island at 0500 HST than 1400 HST (Figs. 12e,f) as a result of more significant blocking. A downslope wind component is evident on the eastern slopes of Haleakalā and over the Kohala Mountains at 0500 HST as well (Figs. 12a,b).

In response to solar heating, upslope flow occurs on the eastern windward slopes of Maui and over the northeastern and northwestern coasts of the Big Island (Fig. 12a) in the afternoon. With reduced stability due to solar heating, the incoming SE flow moves over Cape Laupāhoehoe and the Kohala Mountains with more ease, which results in pronounced warming (Fig. 12c) and drying (Fig. 12e) downstream of the cape and off the western leeside coast. Warming and drying downstream of the northeastern and southeastern coasts of Maui is also more significant at 1400 HST than 0500 HST (Figs. 12c,d). Strengthened pressure gradients through the channel (Figs. 12a,b) in the afternoon result in faster winds downstream of the southeastern Maui coast and in 



FIG. 14. A subtraction of mean simulated meteorological fields for 6 Feb from $21 \mathrm{Feb}$. (a) 10-m winds (shaded, $\mathrm{m} \mathrm{s}^{-1}$ ) and sea level pressure (contours, $\mathrm{Pa}$ ) in the $6-\mathrm{km}$ domain and (b) 10-m winds (shaded, $\mathrm{m} \mathrm{s}^{-1}$ ) and sea level pressure (contours, $\mathrm{Pa}$ ) for the nested 2-km domain. (c) As in (b), but for sea level pressure gradients $\left(\mathrm{Pa} \mathrm{km}^{-1}\right)$.

the Laupāhoehoe tip jet than in the early morning (Figs. 12a,b).

\section{c. Southeast flow variations under different wind direction}

In the 6-km regional domain, the SE flow days exhibit variations in the upstream flow (appendix D), with wind direction between $95^{\circ}$ and $135^{\circ}$, owing to the relative position of an approaching midlatitude front. Figures $4 \mathrm{c}$ and $4 \mathrm{~d}$ reveal the two most disparate variations in wind direction within the composite, with the ESE $\left(107^{\circ}\right)$ flow (Fig. 4c) on 21 February showing faster airflow through the channel than the true SE (SE true) $\left(126^{\circ}\right)$ flow of 6 February. For the ESE case, the tail of the tip jet downstream of Cape Laupāhoehoe reaches the southeastern end of Maui and the northeastern Maui coast (Fig. 4c) while the remainder of the island chain is in the Big Island wake. For the true SE flow, almost the entire island chain is in the Big Island wake (Fig. 4d).

In the ESE case, the tip jet impinges upon the SE slopes of Haleakalā with orographic blocking and splitting airflow on the eastern end of Maui (Fig. 13a). Descending motion with adiabatic warming is simulated as the southern branch of the splitting airflow moves down the southern Maui terrain (Fig. 13c). The development of channel pressure gradients $\left(2-3 \mathrm{~Pa} \mathrm{~km}^{-1}\right)$ occurs off the southern Maui shore (Fig. 13a) yielding $7-8 \mathrm{~m} \mathrm{~s}^{-1}$ winds in the northern part of the channel exit. The TPW is lower over the north-northeastern coast of the Big Island and in the leeside of the Kohala Mountains and is slightly higher on the southeastern coast of Maui, decreasing southwestward under the descending airflow (Fig. 13e).

For the SE true case, the flow downstream of Cape Laupāhoehoe merely grazes Haleakalā's eastern corner resulting in weak $\left(\sim 4 \mathrm{~m} \mathrm{~s}^{-1}\right) \mathrm{NE}$ winds in the channel exit. Vertical motions and corresponding adiabatic temperature adjustments generally have smaller amplitudes and extent than in the ESE case (Fig. 13d), yielding weaker channel pressure gradients $\left(1-2 \mathrm{~Pa} \mathrm{~km}^{-1}\right)$ (Fig. 13b). The TPW is higher along the southeastern Maui coast (Fig. 13f) due to orographic lifting and a moister air mass associated with the increased southerly wind component.

To quantify the orographic influence of Maui and the Big Island on wind and pressure differences in the channel during the aforementioned SE flow variations, the SE true case is subtracted from the ESE case (Fig. 14a). At $19.75^{\circ} \mathrm{N}$, $154.25^{\circ} \mathrm{W}$, the ESE case demonstrates upstream $\mathrm{E}$ wind speeds with a magnitude of $1-3 \mathrm{~m} \mathrm{~s}^{-1}$ greater than the SSE case. Stronger SE winds off Cape Laupāhoehoe with speeds $2-6 \mathrm{~m} \mathrm{~s}^{-1}$ greater in the ESE example are well oriented toward the south shore of Haleakalā and clearly impinge upon it (Fig. 14b). Because this airflow directly impacts the slopes of Haleakalā, pressure perturbations along SE Maui (Fig. 14b) and across the channel entrance are 30-60 Pa greater for the ESE case than the true SE flow. Consequently, channel pressure gradients are $0.5-2 \mathrm{~Pa} \mathrm{~km}^{-1}$ 



FIG. 15. (a) Mean 10-m winds (shaded, $\mathrm{m} \mathrm{s}^{-1}$ ) and sea level pressure (contours, hPa) for 21 Feb in the 6-km domain with Maui County terrain removed. (b) Subtraction of simulations without Maui County terrain from the control run for the mean 10-m winds (shaded, $\mathrm{m} \mathrm{s}^{-1}$ ) and sea level pressure (contours, Pa) in the 6-km domain. (c) As in (b), but for the nested 2-km domain. (d) As in (c), but for sea level pressure gradients $\left(\mathrm{Pa} \mathrm{km}^{-1}\right)$.

greater for the ESE flow regime as compared with the SE true conditions (Fig. 14c), translating to a $3-5 \mathrm{~m} \mathrm{~s}^{-1}$ difference in the northern channel exit wind speed (Fig. 14b). Increased airflow speed at Cape Laupāhoehoe is in response to stronger (1-3 $\left.\mathrm{Pa} \mathrm{km}^{-1}\right)$ local pressure gradients as well.

For the SE flow, channel pressure gradients are dependent on the degree to which the approaching winds impinge directly on the slopes of Haleakalā. Overall, winds in the channel exit are the strongest under summer ENE trades and become progressively weaker as the prevailing winds turn clockwise. The trends associated with E flow progressing toward SE flow include, weaker channel flow becoming confined to the northern portion of the channel, increasing speed of the Laupāhoehoe tip jet, and greater impact of Big Island and Maui wakes on the rest of the island chain.

\section{Sensitivity tests}

In this section, two sensitivity tests for the ESE flow are simulated, in which the islands of Maui and Hawaii are respectively removed and replaced with an ocean surface, to investigate the impacts of orographic blocking by both islands on the channel winds and airflow in the wake zones.

\section{a. Removal of Maui County}

With the topography of Maui County removed, the simulation demonstrates modifications to surface pressure upwind of Haleakalā, within the channel and downstream (Figs. 15a,b). For instance, pressure perturbations are as great as $40+\mathrm{Pa}$ along parts of the SE coast of Maui with flow deceleration upwind of the island and splitting airflow as a result of blocking (Fig. 15c). Orographic blocking also induces pressure gradients along the north side of the channel (2-4 $\left.\mathrm{Pa} \mathrm{km}^{-1}\right)$ (Fig. 15d) corresponding to a wind speed difference of $4-6 \mathrm{~m} \mathrm{~s}^{-1}$ northeasterlies over a broad area of the channel exit (Fig. 15c).

This sensitivity test also shows that a portion of the Kohala and Kona wake return flow is strengthened $\left(1-3 \mathrm{~m} \mathrm{~s}^{-1}\right)$ by positive pressure perturbations extending from the upwind side of Maui southwestward to the leeside of the Big Island. The wake induced by Haleakala under the ESE flow regime covers Molokai and Lānai, and affects the eastern shore of Oahu (Fig. 15b).

\section{b. Removal of the Big Island}

Removing the Big Island (Fig. 16a) eliminates the channel winds and replaces them with orographic 

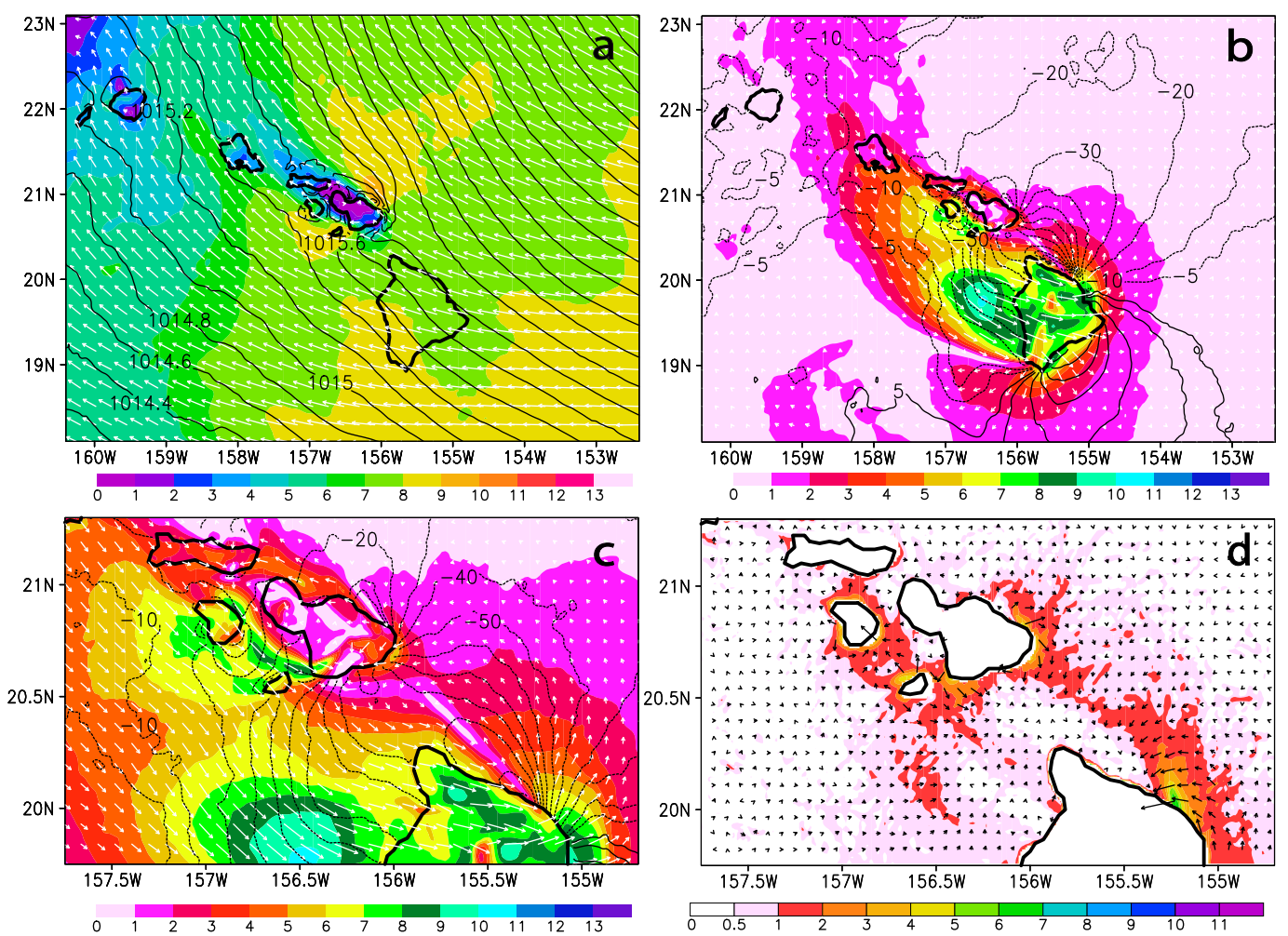

FIG. 16. As in Fig. 15, but for the Big Island.

blocking at Haleakalā resulting in tip jets along the southwest and northeast tips of Maui. The Big Island induces far-reaching positive pressure perturbations to its southeast (up to $40+\mathrm{Pa}$ in magnitude) (Fig. 16b). Under ESE flow, the Big Island wake zone extends northwestward covering Maui, Lānai, Molokai, Oahu, and the ocean east of Kauai.

Positive pressure perturbations associated with orographic blocking and negative pressure perturbations associated with descending airflow downstream of Cape Laupāhoehoe (Figs. 16b,c) contribute to orographically induced pressure gradients resulting in the Laupāhoehoe tip jet. These gradients (up to $7 \mathrm{~Pa} \mathrm{~km}^{-1}$ ) (Fig. 16d) produce a maximum wind speed difference of $7-9 \mathrm{~m} \mathrm{~s}^{-1}$ in the tip jet region (Fig. 16c). The resulting tip jet winds collide with the SE slopes of Haleakalā with orographically induced positive pressure perturbations on the upwind side of Maui and $\mathrm{NE}$ winds in the northern part of the channel exit (Fig. 13a).

\section{Summary and discussion}

Synoptic climatology of the Hawaiian coastal waters indicates a seasonal shift in the mean prevailing winds, favoring a more ESE direction and slower speeds in winter. Historical buoy data reflect greater variability in upstream wind direction and speed during the winter season with a significant number of occurrences of $\mathrm{E}, \mathrm{SE}$, and high wind days. The buoys also indicate significant orographic effects on airflow within the 'Alenuihāhā Channel, which is further modulated by the diurnal cycle. In this study, it is shown that the variations in the wind direction under the ESE flow regime lead to differences in flow interaction with the Big Island, Maui, and the channel. A schematic of the terrain interactions and the flow through the channel under ESE flow regimes during the cool season is given in Fig. 17.

An investigation of an $\mathrm{E}$ wind event reveals changes in the location and intensity of channel wind accelerations compared to ENE trades. These changes are related to orographic blocking by the Big Island and Maui. The strongest winds occur in the channel exit; however, these winds are significantly weaker $\left(\sim 4 \mathrm{~m} \mathrm{~s}^{-1}\right)$ than during trade winds of a commensurate upstream speed $\left(\sim 7-8 \mathrm{~m} \mathrm{~s}^{-1}\right)$. Less airflow convergence at the channel entrance, lower pressure in the southern channel entrance due to a stronger tip jet downstream of Cape Laupāhoehoe, and weaker descending airflow in the leeside of the mountains bordering the channel are among the reasons for overall weaker channel pressure 



\section{) Orographic blocking}



FIG. 17. Schematic of principle airflow regimes in the nested 2-km domain: (a) the E flow on 2 Feb 2011 (06001900 HST), (b) the ESE flow of 21 Feb 2011, and (c) the SE true flow of 6 Feb 2011. Background is WRF mean 10-m wind speed (shaded, $\mathrm{m} \mathrm{s}^{-1}$ ).

gradients during the E flow regime. For this regime, channel winds are orientated along an east-west axis as compared with an ENE-WSW axis during trade winds, with maximum speeds in the northern half of the channel and markedly slower speeds (up to $9 \mathrm{~m} \mathrm{~s}^{-1}$ ) in the southern region. Sounding data gathered within the channel showed that a hydraulic jump was likely to occur in the channel exit during this E flow event.

Channel pressure gradients and channel winds become progressively weaker as the upstream flow adopts a more southerly component. During the ESE flow regime, Big Island orographic blocking shifts to the southeastern coast. The northern branch of the splitting airflow moves over the eastern ridges of Mauna Kea resulting in large pressure gradients downstream of Cape Laupāhoehoe, and a stronger tip jet. The tip jet has a more southerly component as the upstream flow turns more southerly. The blocking of the tip jet on the southeastern end of Maui and the channel pressure gradients depend on the direction and strength of the incoming tip jet. In the absence of blocking by the Kohala Mountains, pressure gradients are weaker in the central and southern channel as compared with the ENE trade wind case.

Respective removal of Maui and Big Island terrain from the simulated ESE flow case reveals the interplay of orographic effects between the two islands on channel airflow. Strong positive pressure perturbations along the Big Island's southeast coast $(40+\mathrm{Pa})$ with negative pressure perturbations in the lee of Cape Laupāhoehoe (up to $7 \mathrm{~Pa} \mathrm{~km}^{-1}$ ) result in a SE tip jet. These tip jet winds encounter the SE slopes of Haleakalā resulting in orographically induced pressure perturbations $(40+\mathrm{Pa})$ in the northern part of the channel. Further modification of channel winds occurs due to diurnal variations in the speed and orientation of the Laupāhoehoe tip jet.

Acknowledgments. This work is supported jointly by the National Science Foundation under Grant AGS1142558 and the Office of Insular Affairs Technical Assistance Program under Grant 18AP00090. This work was also partially funded by the COMET/UCAR under Grant SUBAWD001374. The WHOI Hawaii Ocean Time-Series Station (WHOTS/51WHO) is funded by the Climate Observation Division of the National Oceanic and Atmospheric Administration (NOAA) Climate Program Office. The authors thank Dr. Roger Lukas for making the $51 \mathrm{WHO}$ buoy data available to us, and May Izumi for editing the text. The authors also thank the crew of the R/V Kilo Moana as well as Cyrus Camp and Daniel Büttner for assisting in sounding launches. 

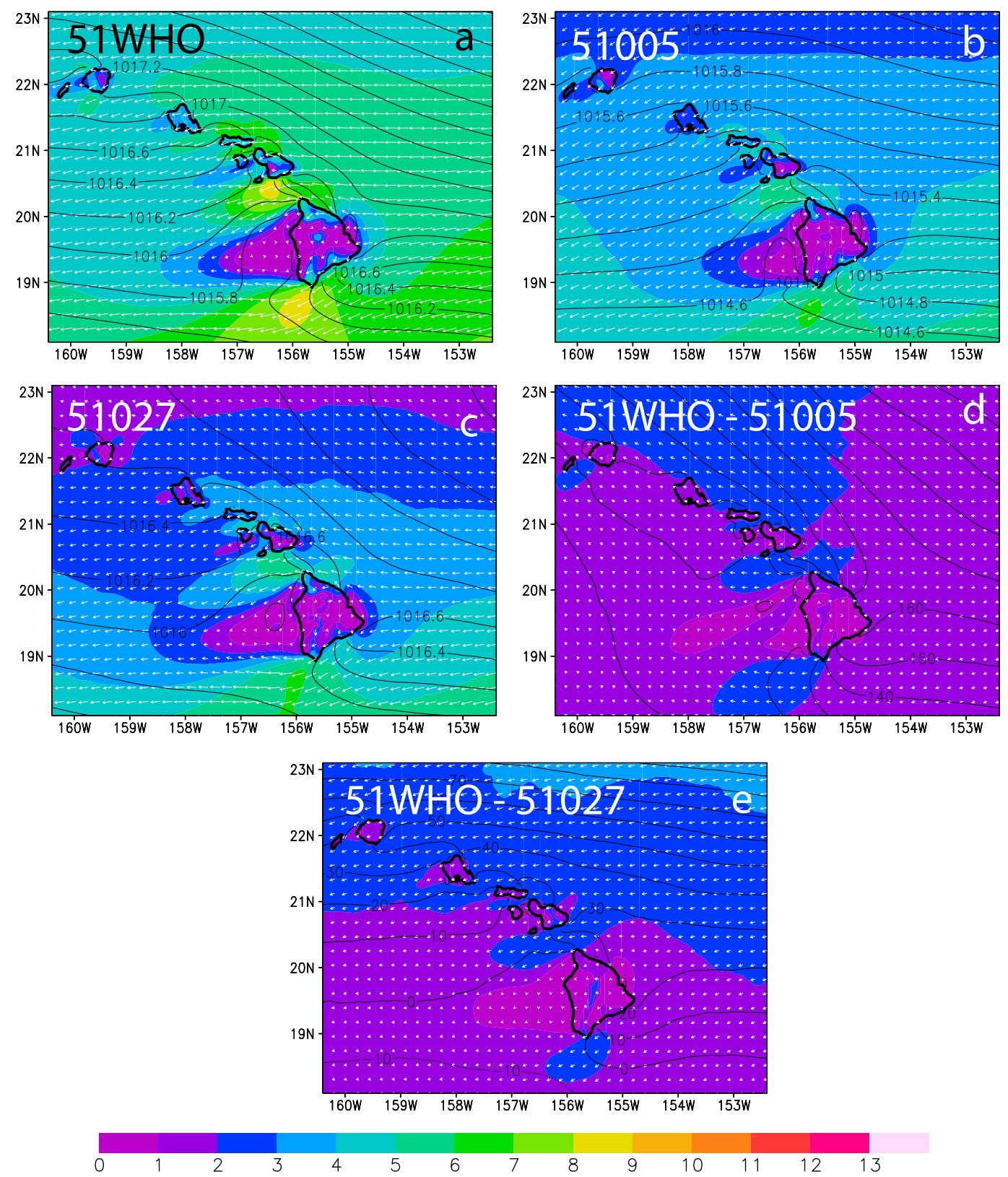

FIG. A1. Mean 10-m winter (DJF) WRF 6-km winds (shaded, $\mathrm{m} \mathrm{s}^{-1}$ ) and sea level pressure (contours, hPa) for the period in which each buoy was in operation: (a) 51WHO (1 Dec 2004-29 Feb 2008), (b) 51005 (9 Dec 1985-29 Feb 1988), and (c) 51027 (7 Dec 1994-28 Feb 1995). (d),(e) The subtraction of the respective channel buoy period from the period in which buoy $51 \mathrm{WHO}$ was in operation.

\section{APPENDIX A}

\section{Buoy Wind Comparison}

Figure A1 shows the mean winter (DJF) surface winds and pressure gradients for the periods in which each buoy was in operation as well as their differences.

\section{APPENDIX B}

\section{Simulated and Observed 'Alenuihāhā Channel Soundings}

Figure B1 shows the evolution of the observed and simulated inversion height and strength through the 'Alenuihāhā Channel on 2 February 2011. 

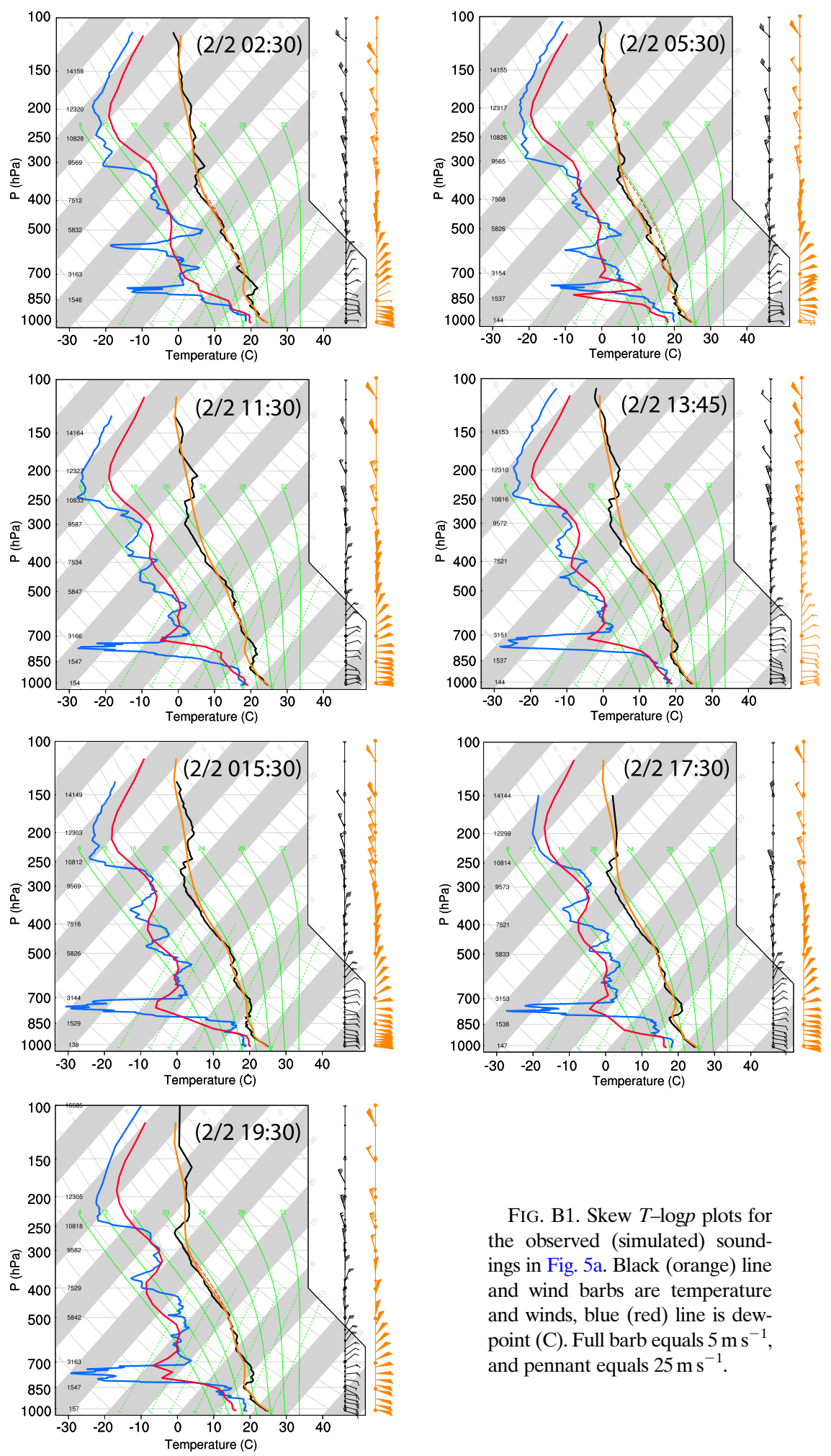

FIG. B1. Skew $T-\log p$ plots for the observed (simulated) soundings in Fig. 5a. Black (orange) line and wind barbs are temperature and winds, blue (red) line is dewpoint (C). Full barb equals $5 \mathrm{~m} \mathrm{~s}^{-1}$, and pennant equals $25 \mathrm{~m} \mathrm{~s}^{-1}$. 
Speed
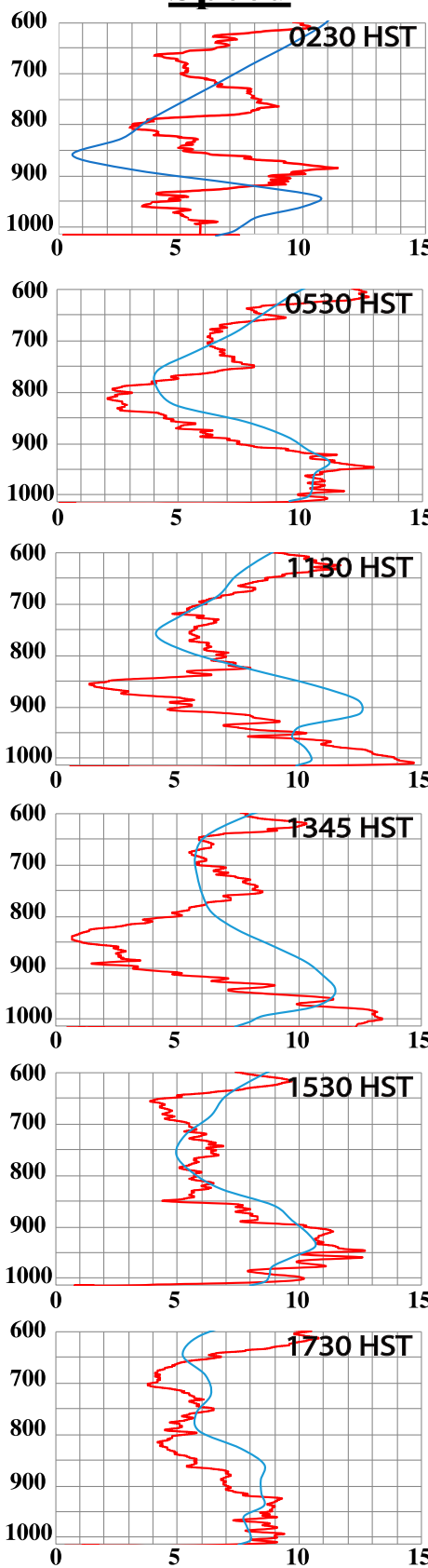

15


FIG. C1. Observed (red) and simulated (blue) vertical profiles of wind speed $\left(\mathrm{m} \mathrm{s}^{-1}\right)$ and direction $\left(^{\circ}\right)$ in the nested 2-km domain for the channel soundings in Fig. 5a. 

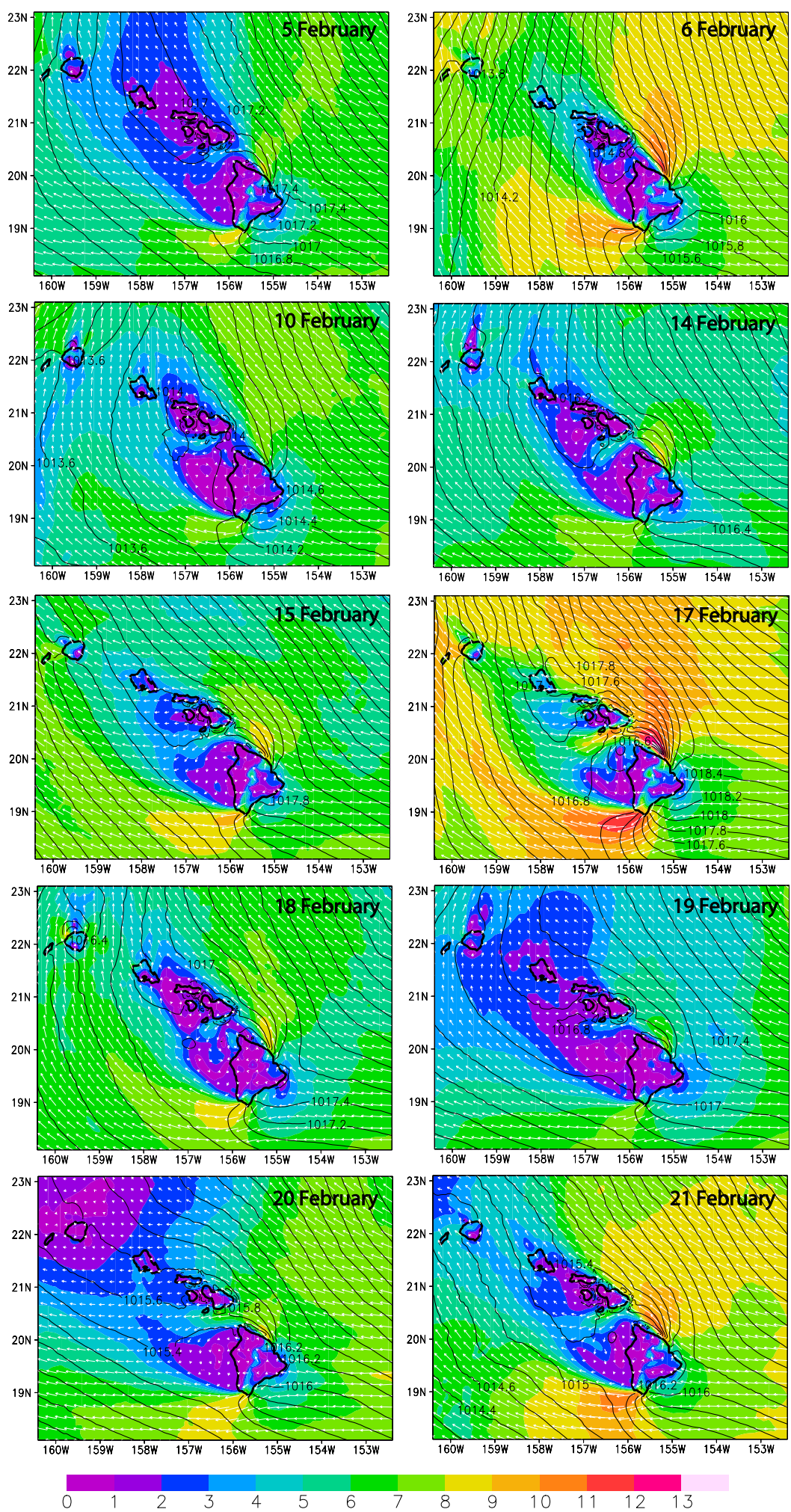

FIG. D1. Mean 10-m winds (shaded, $\mathrm{m} \mathrm{s}^{-1}$ ) and sea level pressure (contours, $\mathrm{hPa}$ ) in the WRF 6-km domain for each day of February 2011 in the 10-day SE composite. 


\section{APPENDIX C}

\section{Verification of the Simulated Vertical Wind Profiles}

Figure $\mathrm{C} 1$ shows verification of the simulated wind speed $\left(\mathrm{m} \mathrm{s}^{-1}\right)$ and wind direction $\left(^{\circ}\right)$ vertical profiles.

\section{APPENDIX D}

\section{Mean Surface Winds and Pressure for Each Day Associated with the SE Composite}

Figure D1 shows the mean surface winds and pressure gradients for the days included in the SE composite.

\section{REFERENCES}

Baines, P. G., 1995: Topographic Effects in Stratified Flow. Cambridge University Press, 496 pp.

Blumenstock, D. I., and S. Price, 1967: Climate of Hawaii. Climates of the States, No. 60-51, Climatography of the United States, U.S. Department of Commerce, 614-639.

Carlis, D. L., Y.-L. Chen, and V. R. Morris, 2010: Numerical simulations of island-scale airflow over Maui and the Maui vortex under summer trade wind conditions. Mon. Wea. Rev., 138, 2706-2736, https://doi.org/10.1175/2009MWR3236.1.

Chen, F., and J. Dudhia, 2001: Coupling an advanced land surface/hydrological model with the Penn State/NCAR MM5 modeling system. Part I: Model implementation and sensitivity. Mon. Wea. Rev., 129, 569-585, https://doi.org/ 10.1175/1520-0493(2001)129<0569:CAALSH > 2.0.CO;2.

Chen, Y.-L., and A. J. Nash, 1994: Diurnal variation of surface airflow and rainfall frequencies on the island of Hawaii. Mon. Wea. Rev., 122, 34-56, https://doi.org/10.1175/1520-0493(1994) $122<0034$ :DVOSAA $>2.0$. CO 2 .

_ distributions over the windward side of the island of Hawaii. Part I: The effects of trade-wind inversion. Mon. Wea. Rev., 129, 1117-1134, https://doi.org/10.1175/1520-0493(2001)129<1117: NSOAAC $>2.0 . \mathrm{CO} ; 2$.

— Y.-J. Chu, C.-S. Chen, C.-C. Tu, J.-H. Teng, and P.-L. Lin, 2018: Analysis and simulations of a heavy rainfall event over northern Taiwan during 11-12 June 2012. Mon. Wea. Rev., 146, 2697-2715, https://doi.org/10.1175/MWR-D-18-0001.1.

Dorman, C. E., R. C. Beardsley, and R. Limeburner, 1995: Winds in the Strait of Gibraltar. Quart. J. Roy. Meteor. Soc., 121, 1903-1921, https://doi.org/10.1002/qj.49712152807.

Dudhia, J., 1989: Numerical study of convection observed during the Winter Monsoon Experiment using a mesoscale twodimensional model. J. Atmos. Sci., 46, 3077-3107, https://doi.org/ 10.1175/1520-0469(1989)046<3077:NSOCOD>2.0.CO;2.

Esteban, M. A., and Y.-L. Chen, 2008: The impact of trade-wind strength on precipitation over the windward side of the island of Hawaii. Mon. Wea. Rev., 136, 913-928, https://doi.org/ 10.1175/2007MWR2059.1.

Frye, J., and Y.-L. Chen, 2001: Evolution of downslope flow under strong opposing trade winds and frequent trade-wind rainshowers over the island of Hawaii. Mon. Wea. Rev., 129, 956-977, https://doi.org/10.1175/1520-0493(2001)129<0956: EODFUS $>2.0 . \mathrm{CO} ; 2$.
Gaberšek, S., and D. R. Durran, 2004: Gap flows through idealized topography. Part I: Forcing by large-scale winds in the nonrotating limit. J. Atmos. Sci., 61, 2846-2862, https://doi.org/ 10.1175/JAS-3340.1.

Hitzl, D. E., Y.-L. Chen, and H. V. Nguyen, 2014: Numerical simulations and observations of airflow through the 'Alenuihāhā Channel, Hawaii. Mon. Wea. Rev., 142, 4696-4718, https:// doi.org/10.1175/MWR-D-13-00312.1.

Hong, S., Y. Noh, and J. Dudhia, 2006: A new vertical diffusion package with an explicit treatment of entrainment processes. Mon. Wea. Rev., 134, 2318-2341, https://doi.org/ 10.1175/MWR3199.1.

Hsu, S. A., E. A. Meindl, and D. B. Gilhousen, 1994: Determining the power-law wind profile exponent under near-neutral stability conditions at sea. J. Appl. Meteor., 33, 757-765, https://doi.org/10.1175/1520-0450(1994)033<0757: DTPLWP $>2.0$. CO;2.

Janjić, Z. I., 1994: The step-mountain Eta coordinate model: Further developments of the convection, viscous sublayer, and turbulence closure schemes. Mon. Wea. Rev., 122, 927-945, https://doi.org/10.1175/1520-0493(1994)122<0927: TSMECM $>2.0 . \mathrm{CO} ; 2$.

Kalnay, E., and Coauthors, 1996: The NCEP/NCAR 40-Year Reanalysis Project. Bull. Amer. Meteor. Soc., 77, 437-470, https://doi.org/10.1175/1520-0477(1996)077<0437:TNYRP> 2.0.CO;2.

Kapustin, V. N., A. D. Clarke, S. G. Howell, C. S. McNaughton, V. L. Brekhovskikh, and J. Zhou, 2012: Evaluating primary marine aerosol production and atmospheric roll structures in Hawaii's natural oceanic wind tunnel. J. Atmos. Oceanic Technol., 29, 668-682, https://doi.org/10.1175/JTECH-D-11-00079.1.

Kodama, K., and G. M. Barnes, 1997: Heavy rain events over the south-facing slopes of Hawaii: Attendant conditions. Wea. Forecasting, 12, 347-367, https://doi.org/10.1175/1520-0434(1997) 012<0347:HREOTS $>2.0$. CO; .

Lackmann, G. M., and J. E. Overland, 1989: Atmospheric structure and momentum balance during a gap-wind event in Shelikof Strait, Alaska. Mon. Wea. Rev., 117, 1817-1833, https://doi.org/ 10.1175/1520-0493(1989)117<1817:ASAMBD>2.0.CO;2.

Leopold, L. B., 1949: The interaction of trade wind and sea breeze, Hawaii. J. Meteor., 6, 312-320, https://doi.org/10.1175/15200469(1949)006<0312:TIOTWA $>2.0 . \mathrm{CO} ; 2$.

Mass, C. F., S. Businger, M. D. Albright, and Z. A. Tucker, 1995: A windstorm in the lee of a gap in a coastal mountain barrier. Mon. Wea. Rev., 123, 315-331, https://doi.org/10.1175/15200493(1995)123<0315:AWITLO > 2.0.CO;2.

Nguyen, H., Y. Chen, and F. Fujioka, 2010: Numerical simulations of island effects on airflow and weather during the summer over the island of Oahu. Mon. Wea. Rev., 138, 2253-2280, https://doi.org/10.1175/2009MWR3203.1.

Overland, J. E., 1984: Scale analysis of marine winds in straits and along mountainous coasts. Mon. Wea. Rev., 112, 25302534, https://doi.org/10.1175/1520-0493(1984)112<2530: SAOMWI $>2.0 . \mathrm{CO} ; 2$.

, and B. A. Walter, 1981: Gap winds in the Strait of Juan de Fuca. Mon. Wea. Rev., 109, 2221-2233, https://doi.org/10.1175/ 1520-0493(1981)109<2221:GWITSO > 2.0.CO;2.

Patzert, W. C., 1969: Eddies in Hawaiian waters. HIG Rep. HIG69-8, Hawaii Institute of Geophysics, University of Hawaii at Manoa, Honolulu, HI, 51 pp.

Reed, T. R., 1931: Gap winds of the Strait of Juan de Fuca. Mon. Wea. Rev., 59, 373-376, https://doi.org/10.1175/1520-0493(1931) 59<373:GWOTSO > 2.0.CO;2. 
Rogers, E., T. Black, B. Ferrier, Y. Lin, D. Parrish, and G. DiMego, 2001: Changes to the NCEP meso eta analysis and forecast system: Increase in resolution, new cloud microphysics, modified precipitation assimilation, and modified 3DVAR analysis. NWS Technical Procedures Bull. 488, NOAA/NWS

Schär, C., and R. B. Smith, 1993: Shallow-water flow past isolated topography. Part I: Vorticity production and wake formation. J. Atmos. Sci., 50, 1373-1400, https://doi.org/10.1175/15200469(1993)050<1373:SWFPIT > 2.0.CO;2.

Schroeder, T. A., 1993: Climate controls. Prevailing Trade Winds: Weather and Climate in Hawaii, M. Sanderson, Ed., University of Hawai'i Press, 12-36.

Schultz, D. M., W. E. Bracken, L. F. Bosart, G. J. Hakim, M. A. Bedrick, M. J. Dickinson, and K. R. Tyle, 1997: The 1993 superstorm cold surge: Frontal structure, gap flow, and tropical impact. Mon. Wea. Rev., 125, 5-39, https://doi.org/10.1175/ 1520-0493(1997)125<0005:TSCSFS > 2.0.CO;2.

$\ldots, \ldots$, and $—$, 1998: Planetary- and synoptic-scale signatures associated with Central American cold surges. Mon. Wea. Rev., 126, 5-27, https://doi.org/10.1175/1520-0493(1998)126<0005: PASSSA $>2.0 . \mathrm{CO} ; 2$.

Scorer, R. S., 1952: Mountain-gap winds; a study of surface wind at Gibraltar. Quart. J. Roy. Meteor. Soc., 78, 53-61, https:// doi.org/10.1002/qj.49707833507.

Sharp, J., and C. F. Mass, 2004: Columbia gorge gap winds: Their climatological influence and synoptic evolution. Wea. Forecasting, 19, 970-992, https://doi.org/10.1175/826.1.

Skamarock, W. C., and J. B. Klemp, 2008: A time-split nonhydrostatic atmospheric model for weather research and forecasting applications. J. Comput. Phys., 227, 3465-3485, https://doi.org/10.1016/j.jcp.2007.01.037.

Smith, R. B., 1989: Mountain-induced stagnation points in hydrostatic flow. Tellus, 41A, 270-274, https://doi.org/10.1111/ j.1600-0870.1989.tb00381.x.

— J. Atmos. Sci., 50, 3728-3750, https://doi.org/10.1175/15200469(1993)050<3728:AOOHW >2.0.CO;2.

Smolarkiewicz, P. K., and R. Rotunno, 1989: Low Froude number flow past three-dimensional obstacles. Part I: Baroclinically generated lee vortices. J. Atmos. Sci., 46, 1154-1164, https:// doi.org/10.1175/1520-0469(1989)046<1154:LFNFPT>2.0.CO;2.

-, R. M. Rasmussen, and T. L. Clark, 1988: On the dynamics of Hawaiian cloud bands: Island forcing. J. Atmos. Sci., 45,
1872-1905, https://doi.org/10.1175/1520-0469(1988)045<1872: OTDOHC $>2.0 . \mathrm{CO} ; 2$.

Steenburgh, W. J., D. M. Schultz, and B. A. Colle, 1998: The structure and evolution of gap outflow over the Gulf of Tehuantepec, Mexico. Mon. Wea. Rev., 126, 2673-2691, https://doi.org/ 10.1175/1520-0493(1998)126<2673:TSAEOG > 2.0.CO;2.

Stopa, J. E., K. F. Cheung, and Y.-L. Chen, 2011: Assessment of wave energy resources in Hawaii. J. Renewable Energy, 36, 554-567, https://doi.org/10.1016/j.renene.2010.07.014.

_- J.-F. Filipot, N. Li, K. F. Cheung, Y.-L. Chen, and L. Vega, 2013: Wave energy resources along the Hawaiian Island chain. Renewable Energy, 55, 305-321, https://doi.org/ 10.1016/j.renene.2012.12.030.

Tam, E. K., and Coauthors, 2016: Volcanic air pollution over the Island of Hawai'i: Emissions, dispersal, compositionAssociation with respiratory symptoms and lung function in Hawaii Island School children. Environ. Int., 92-93, 543552, https://doi.org/10.1016/j.envint.2016.03.025.

Winning, T., Y.-L. Chen, and F. Xie, 2017: Estimation of the marine boundary layer height over the central north Pacific using GPS radio occultation. Atmos. Res., 183, 362-370, https:// doi.org/10.1016/j.atmosres.2016.08.005.

Worthley, L. E., 1967: Synoptic climatology of Hawaii. Weather Phenomena in Hawaii, Part I, Hawaii Institute of Geophysics Rep. 67-9, Department of Meteorology, University of Hawaii at Manoa, Honolulu, HI, 40 pp.

Yang, Y., and Y.-L. Chen, 2008: Effect of terrain heights and sizes on island-scale circulations and rainfall for the island of Hawaii during HaRP. Mon. Wea. Rev., 136, 120-146, https:// doi.org/10.1175/2007MWR1984.1.

—_ _ _ and F. Fujioka, 2005: Numerical simulations of the island-induced circulations over the island of Hawaii during HaRP. Mon. Wea. Rev., 133, 3693-3713, https://doi.org/ 10.1175/MWR3053.1.

Zhang, Y., Y.-L. Chen, S.-Y. Hong, H.-M. H. Juang, and K. Kodama, 2005a: Validation of the coupled NCEP Mesoscale Spectral Model and an advanced land surface model over the Hawaiian Islands. Part I: Summer trade wind conditions and a heavy rainfall event. Wea. Forecasting, 20, 847-872, https://doi.org/10.1175/WAF891.1.

- - - , and - , 2005b: Validation of the coupled NCEP Mesoscale Spectral Model and an advanced land surface model over the Hawaiian Islands. Part II: A high wind event. Wea. Forecasting, 20, 873-895, https://doi.org/10.1175/WAF892.1. 